\title{
A Taphonomic Interpretation of the Postmortem Fate of the Victims Following the Massacre at Sandby Borg, Sweden
}

\author{
Clara Alfsdotter ${ }^{a *}$ and Anna Kjellström ${ }^{b}$ \\ ${ }^{a}$ Linnaeus University, School of Cultural Studies, Faculty of Art and Humanities, Linnégatan 5, \\ SE-391 82 Kalmar, Sweden \\ ${ }^{\mathrm{b}}$ Archaeological Research Laboratory, Department of Archaeology and Classical Studies, \\ University of Stockholm, Sweden \\ ${ }^{\star}$ Correspondence to: Clara Alfsdotter, Linnaeus University Faculty of Arts and Humanities, Linnégatan 5, \\ SE-391 82 Kalmar, Sweden \\ e-mail: Clara.Alfsdotter@bohuslansmuseum.se
}

ABSTRACT In the ringfort Sandby borg (A.D. 400-550) on Öland, Sweden, remains of 26 unburied humans were excavated between 2010 and 2016. Several of the skeletons display traces of lethal interpersonal violence. This study presents taphonomic analyses of unburied bodies, a situation seldom encountered archaeologically. The depositional context allows us to investigate human taphonomy in interaction with natural agents both "indoors" and "outdoors." A set of various techniques, including documentation of preservation via zoning, weathering stages, fracture analysis, and archaeothanatology, were applied to understand the perimortem and postmortem fate of the human remains. The results of the taphonomic analysis showed no indications of manipulation postmortem. Expected differences in preservation between in- and outdoor skeletons were not observed. Perimortem fire alterations were interpreted as the result of burning hearths and smoldering roofs. The analysis indicates that the bodies have decomposed in voids. New observations for "unconfined void" taphonomy are presented. The abduction of limbs could be the result of bloating and, hence, indicate a primary deposit of bodies. Atypical lack of splaying of bones might be caused by decomposition in unconfined voids, possibly allowing quicker drainage of putrefaction liquids than in confined voids such as coffins. These observations suggest that processes behind decomposition in voids are not completely understood archaeologically, and might challenge interpretations of mortuary treatment from human remains.

Keywords: mortuary archaeology; unburied; human decomposition

In der Wallburg Sandby borg (400-550 n. Chr.) auf Öland, Schweden, wurden die Überreste von 26 nicht bestatteten Menschen gefunden, die zu einem großen Teil Spuren von tödlicher Gewalteinwirkung aufwiesen. In dieser Studie werden die Ergebnisse taphonomischer Untersuchungen von nicht bestatteten menschlichen Überresten präsentiert, auf die man im archäologischen Kontext nur selten trifft. Diese Art der Niederlegung und Auffindung erlaubt es uns die Taphonomie von menschlichen Überresten unter natürlichen Einflüssen von sowohl "drinnen-im Haus" als auch "draußen-außer Haus" zu untersuchen. Mehrere unterschiedliche Methoden wurden angewendet um sowohl das perimortale als auch das postmortale Schicksal der menschlichen Überreste zu verstehen, darunter Dokumentation der bewahrten Knochenteile, Stadien der Verwitterung, Bruchanalysen und Archäothanatologie. Die Ergebnisse der taphonomischen Untersuchungen zeigten keine postmortalen Veränderungen. Die erwarteten Unterschiede im Zustand der drinnen und draußen bewahrten Skeletten ließen sich nicht bestätigen. Perimortale Veränderungen der verbrannten Knochen wurden als Resultat von aktiven Feuerherden und brennenden Dächern gedeutet. Die Analyse spricht dafür, dass die Körper in Hohlräumen verwesten. Neue Beobachtungen von Taphonomie in "unbegrenzten Hohlräumen" werden ebenfalls präsentiert. Die Abduktion von Körpergliedern kann auf Aufblähungen beruhen, und spricht damit für 
eine primäre Niederlegung von Körpern. Der atypische Mangel an verteilten Knochenmaterial kann durch die Verwesung in unbegrenzten Hohlräumen verursacht worden sein, und damit einen schnelleren Abfluss von Verwesungsflüssigkeit erlauben, als es in begrenzten Hohlräumen wie z. B. Särgen der Fall ist. Diese Ergebnisse sprechen dafür, dass Verwesungsprozesse in Hohlräumen archäologisch noch nicht vollständig zu verstehen sind, und daher die Deutung wie menschliche Überreste behandelt wurden in Frage stellen können.

Inside the ringfort Sandby borg on the island Öland in Sweden (Fig. 1), human remains were found in 2010 (e.g., Alfsdotter and Kjellström 2018; Alfsdotter et al. 2018; Dutra Leivas and Victor 2012; Gunnarsson et al. 2016; Victor 2015; Victor et al. 2013). Annual excavations and subsequent analyses have revealed that a large number of the individuals show traces of a violent attack which seemingly led to an abrupt end of the settlement. The artifacts indicate that the event took place during the Iron Age, probably A.D. 400-550 (the Migration period; Alfsdotter et al. 2018). Approximately 53 houses have been identified (Borg et al. 1976;

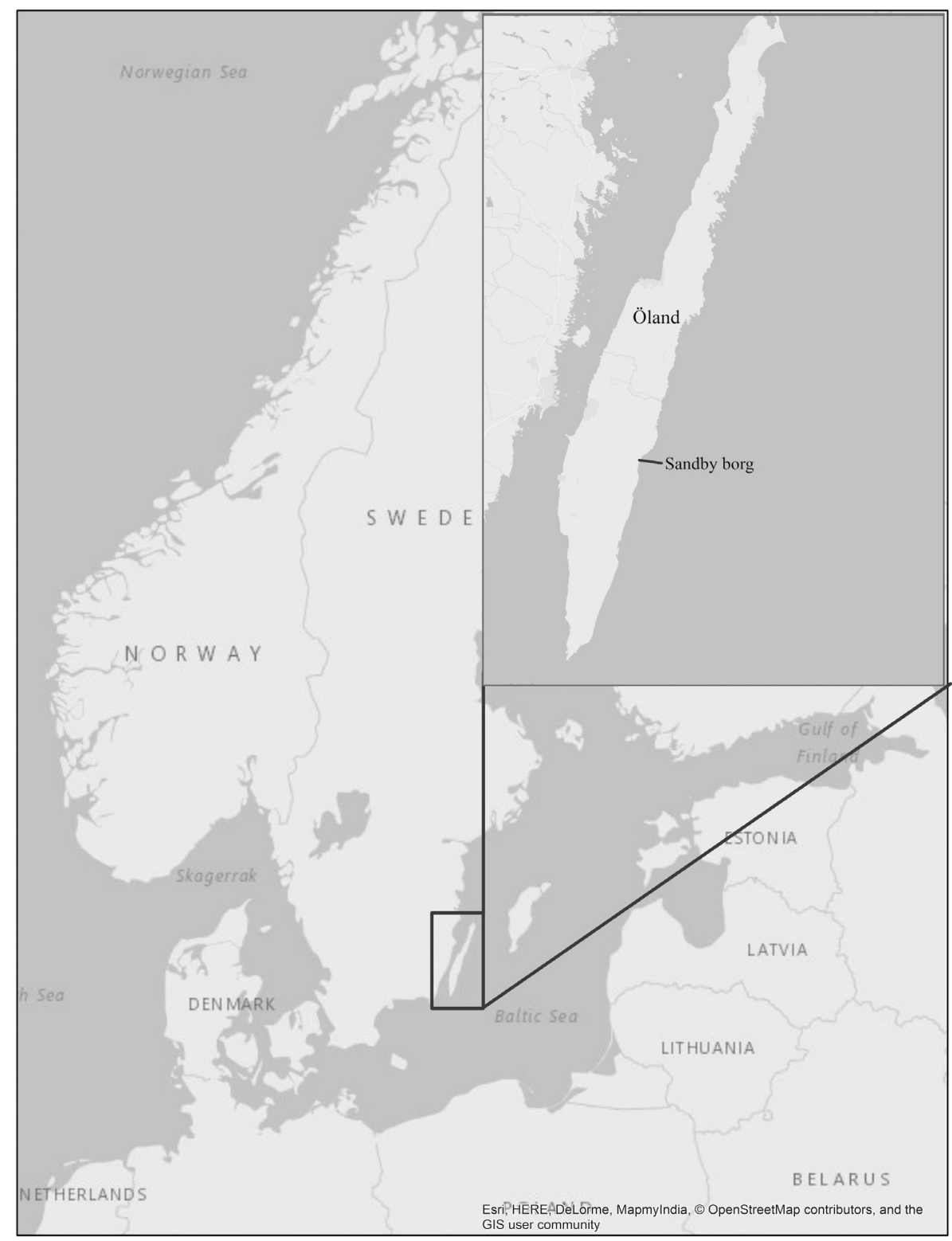

Figure 1. Map of Sweden showing the location of Sandby borg. (Base map ๑ OpenStreetMap contributors, modified by Helena Victor.) 
Viberg et al. 2014). Three houses were completely, and six partly, excavated, amounting to $9 \%$ of the ringfort interior (see Figs. 2, 3, and 4, and Supplement 1). Remnants of everyday life were revealed; ordinary objects as well as high-status jewelry were documented (Gunnarsson et al. 2016; Papmehl-Dufay and Alfsdotter 2016; Victor 2015). In addition, articulated and commingled remains of animals and humans were excavated inside and outside the houses. Skeletal remains from a minimum of 26 humans have been identified, some as complete, articulated skeletons and others represented by single bones or teeth (Alfsdotter in press). Several skeletons show traces of perimortem sharp, blunt, and penetrating trauma consistent with interpersonal violence, implying a lethal attack after which the dead were left unburied in the settlement (Alfsdotter and Kjellström 2018; Alfsdotter et al. 2018). Macrobotanical analysis further confirms the limited activity inside Sandby borg before the subsequent overlay of post-occupational sediment and debris (Heimdahl 2016). The soil samples from the ringfort main street contained burnt threads of turf or hay, consistent with soil samples from some houses. This indicates that turf roofs were partially smoldered. The intact strands of burnt turf on the street indicate that the street was not trampled after the fire that affected some house roofs (Heimdahl, personal communication). The fire was seemingly contemporary with the mass killing, as indicated by the stratigraphic data, the macrobotanical analyses, and the partial thermal alterations of some of the dead humans. Based on the age distribution of lambs that had been slaughtered and dismembered, the assault probably took place sometime between late spring and early autumn (Gunnarsson et al. 2016).

The combination of articulated, disarticulated, and commingled human bones make up a postmortem

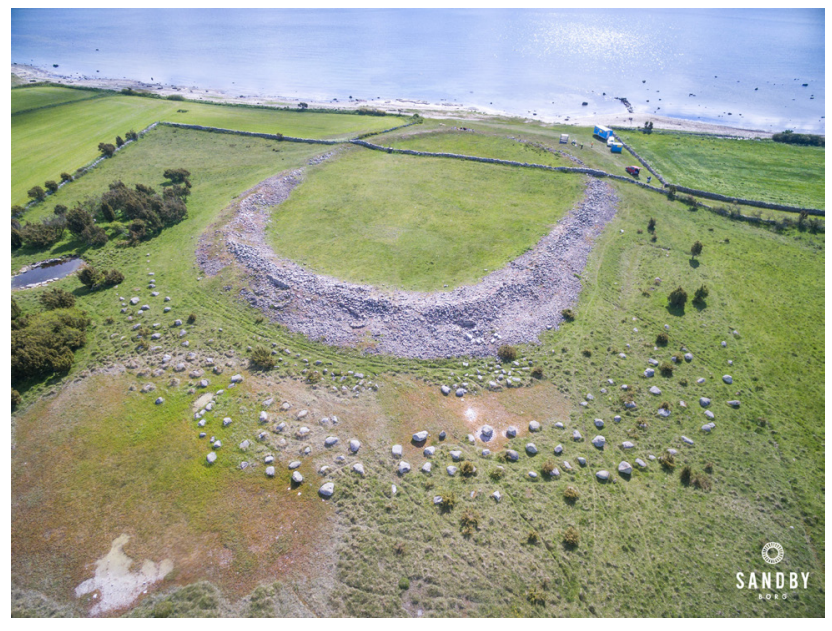

Figure 2. The remains of Sandby borg as visible today. (Photo by Sebastian Jakobsson.) context that is challenging to interpret. Here we apply a set of complementary techniques to facilitate the understanding of the postmortem fate of the victims, with in-depth discussion of some key cases. By separating environmental factors from human actions, we interpret the taphonomic processes that followed the mass killing, and in so doing understand the deposition of the human remains. We focus on human decomposition in voids and propose that the architecture of the void plays a part in the skeletal (dis)articulation. A preliminary study suggested that the bodies were manipulated postmortem and that someone tore down the roof over at least some of the decaying cadavers (Wilhelmson 2017:140-141), an interpretation we discuss in relation to the new taphonomic analyses conducted.

\section{Material and Methods}

Excavations have been undertaken annually at the Sandby borg site by the Kalmar County Museum since 2011. For a detailed description see Supplement 2. Human remains were excavated in all three fully excavated houses $(4,40,52)$ and in three of the six small trenches investigated in other houses $(1,6,53)$. The remains were documented in situ and further analyzed in a laboratory, where an estimation of the minimum number of individuals (MNI) was performed.

\section{MNI, sex, age at death, and trauma}

Advanced disarticulation and commingling of the skeletal remains in outdoor and, to some extent, indoor contexts made assessment of MNI challenging. MNI was calculated based on the most common bone element in the same context (i.e., each house is considered a separate depositional context, whereas the street, while more extensive spatially, is regarded as one archaeological context), in association with element side and, when possible, age of the individual. Bones and articulated skeletons that derive from unique individuals were assigned an ID number. Loose bones that could not be matched to a unique skeleton were only assigned their find numbers (Alfsdotter in press; Gunnarsson et al. 2016; PapmehlDufay and Alfsdotter 2016). Bones with find numbers that were found in association, but not in articulation, with bones belonging to a unique individual have (when the biological profile matches) been proposed as deriving from the same individual. However, these bones are kept separate (except for fragments that have been matched through refitting). Admittedly, since the spatial contexts (i.e., different houses and the surrounding street) were regarded as distinct, there is a 


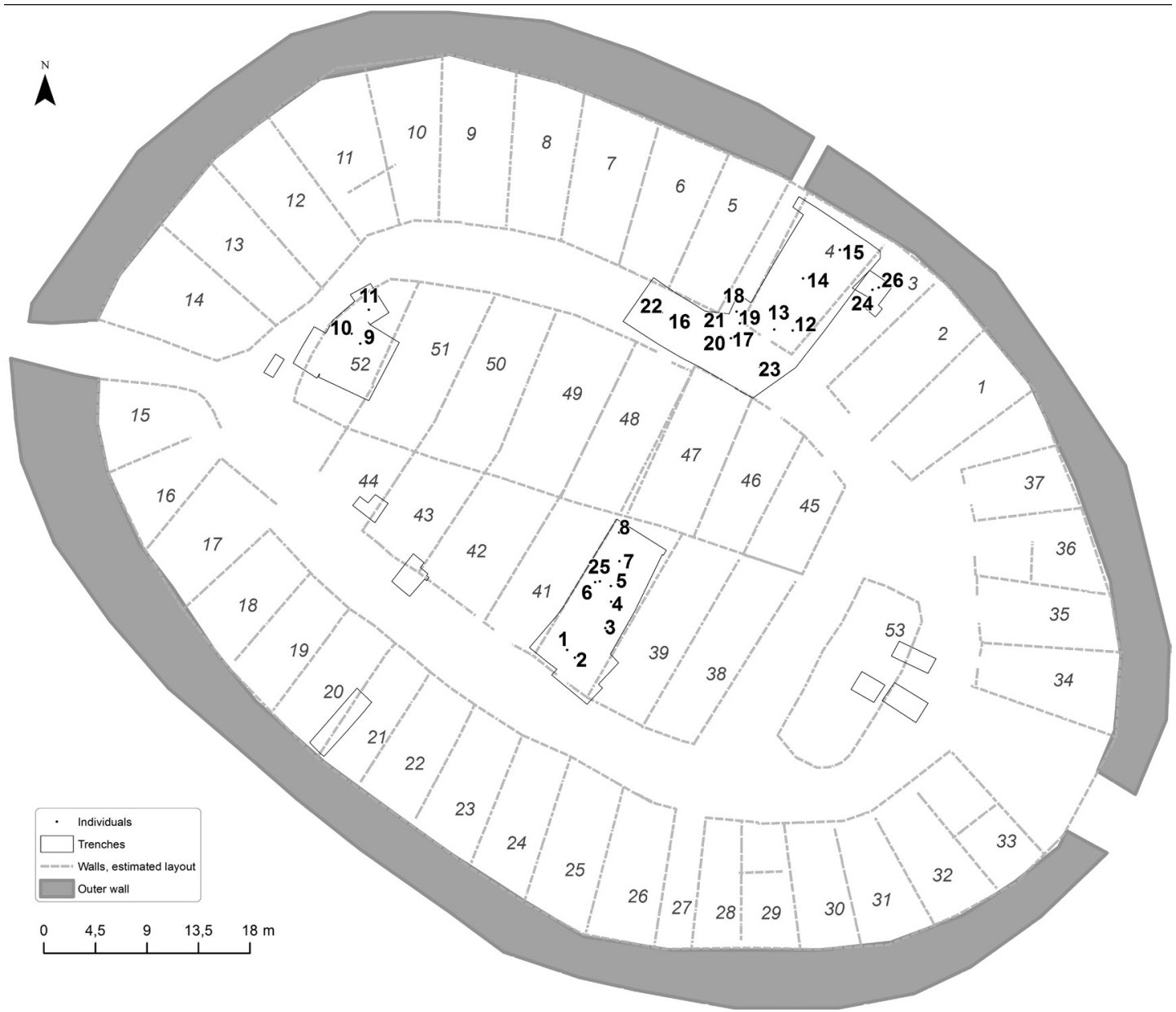

Figure 3. Plan view of Sandby borg with houses numbered (after Viberg 2012). Excavated areas are marked with solid lines. Human remains belonging to unique individuals are indicated by dots and ID numbers in bold. (Figure by Helena Victor.)

risk that animals with access to the houses may have moved bodies or body parts between the different contexts.

Standard osteological techniques were applied for the sex and age-at-death estimations of the individuals (for details regarding methods, see Alfsdotter and Kjellström 2018 and Alfsdotter et al. 2018). All individuals have been assigned to the following age groups: fetal; infants, $0-3$ years; children, $3-12$ years; adolescents, $12-20$ years; young adults, $20-35$ years; middle adults, 35-50 years; old adults, 50+ (Buikstra and Ubelaker 1994:9). The precise age intervals in years must be treated with caution, since the methods used for age estimations rely on biological processes and may not correlate with chronological age (e.g., Roksandic and Armstrong 2011). Table 1 illustrates the demography of the dead. All age groups are represented. The osteological sex estimations among the adults reveal that 8 were males, 2 probable males, and 1 possible female.

Trauma was classified according to Ubelaker (2015) as antemortem, perimortem, or postmortem (see also comments on the fracture analysis below). Perimortem weapon lesions were further categorized according to type (sharp, penetrating, or blunt force trauma). The trauma results are discussed in detail in Alfsdotter and Kjellström (2018).

\section{The taphonomic analysis}

Contexts vary within the ringfort; human remains are found in both open-air and indoor locations, all covered by post-occupational debris and/or soil. This setting calls for a perspective commonly used in forensic taphonomy, where agents and processes that could have affected the bodies are identified (e.g., Haglund and Sorg 1997). Sunlight, for example, would not have bleached the bones of individuals found indoors, while outdoor bodies were not exposed to the falling of debris from collapsing houses (apart from skeletons adjacent to houses that collapsed outward). Temperature exposure and gnawing by small rodents, on the other hand, were probably similar inside and outside the houses due to their crude construction (limestone 


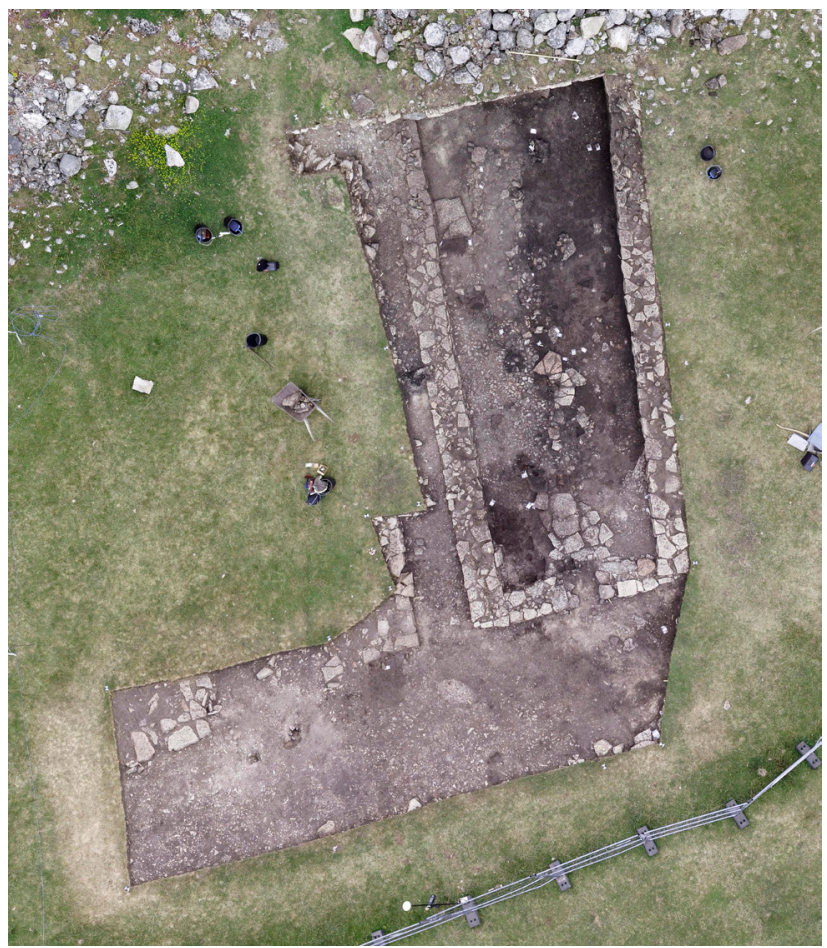

Figure 4. The excavation of house 4, parts of the narrow alley leading up to a small gate (to the left of the house foundation), and part of the street in front of the house. The end wall of house 4 is also the ringfort wall. The gables of houses 5 (parallel with house 4) and 6 are visible in the left of the picture, aligned with the trench wall. (Photo by Sebastian Jakobsson.) walls, turf roofs, and earthen and/or stone-paved floors). Since animals were discovered inside some of the houses, it is clear that trampling and animal gnawing of the bones could occur in both contexts. Also, precipitation must have made the soil wet both indoors and outdoors, which allowed for moisture to penetrate the bones, causing exfoliation or deeper bone cracks due to freeze-thaw conditions (see Supplement 3).

The presence of root etching was investigated macroscopically and documented as present or absent. Destruction in the form of tooth marks from rodents, canids, or pigs was measured, photographed, and compared to known cases of scavenging (Berryman 2002; Haglund 1997a, 1997b). Citing others, Haglund (1997a) lists punctures, pits, scoring, and furrows as typical carnivore tooth marks, most often found on bone margins, crests and protruding processes. Thermal alterations were recorded following the combustion rate scale provided by Stiner et al. (1995). To recognize the variation in postmortem factors that affected the bodies inside and outside the buildings, four different taphonomic techniques were applied (zonation, weathering, fracture analysis and archaeothanatology). To demonstrate the state of preservation of each element, the zonation system by Knüsel and Outram (2004) was used (but due to poor preservation only on humeri and femora). Accordingly, a

Table 1. Overview of MNI, spatial context, sex, age, and preservation of skeletons (data from Alfsdotter in press; Gunnarsson et al. 2016:54-80; and Papmehl-Dufay and Alfsdotter 2016:41-49).

\begin{tabular}{|c|c|c|c|c|c|c|}
\hline ID & $\begin{array}{l}\text { Majority of Skeleton } \\
\text { Articulated (approx. \% } \\
\text { of skeleton preserved) }\end{array}$ & Age (years) & Sex & Thermal Changes & $\begin{array}{l}\text { Perimortem } \\
\text { Trauma }\end{array}$ & Context \\
\hline 1 & Yes $(100)$ & Adolescent (17-19) & M & - & $\mathrm{x}$ & House 40 \\
\hline 2 & Yes (100) & Young adult (19-25) & M & - & $\mathrm{x}$ & House 40 \\
\hline 3 & No $(20)$ & Middle adult & $?$ & Partial (carbonization teeth roots) & $\mathrm{x}$ & House 40 \\
\hline 4 & Yes (75) & Young adult & $\mathrm{M} ?$ & Partial (skull, i.e., cranium \& mandibula) & $\mathrm{x}$ & House 40 \\
\hline 5 & Yes (60) & Young (?) adult & M & $\begin{array}{l}\text { Partial (carbonization few cranial fragments, few rib } \\
\text { fragments, one lumbar spinous process calcined) }\end{array}$ & & House 40 \\
\hline 6 & Yes $(90)$ & Adolescent (12-15) & $?$ & - & $\mathrm{x}$ & House 40 \\
\hline 7 & Yes $(100)$ & Adolescent (12-15) & ? & - & & House 40 \\
\hline 8 & No $(5)$ & Infant/child (ca. 2-5) & $?$ & - & & House 40 \\
\hline 9 & Yes (85) & Old adult & M & $\begin{array}{l}\text { Partial (few fragments with carbonization from } \\
\text { right os coxae, sacrum, ribs) }\end{array}$ & & 52 \\
\hline 10 & No (5) & Infant/child & $?$ & - & & 52 \\
\hline 11 & No (5) & Middle adult & $?$ & - & & 52 \\
\hline 12 & Yes $(80)$ & Child (6-8) & $?$ & & & House 4 \\
\hline 13 & No (40) & Adolescent (10-13) & $?$ & - & $\mathrm{x}$ & House 4 \\
\hline 14 & No $(20)$ & Old (?) adult & $?$ & Partial (carbonization femur) & $\mathrm{x}$ & House 4 \\
\hline 15 & Partial articulation (75) & Old adult & $\mathrm{M}$ & - & & House 4 \\
\hline 16 & No $(20)$ & Middle adult & $?$ & - & & Street \\
\hline 17 & No (5) & Child (5-9) & $?$ & - & & Street/alley \\
\hline 18 & No $(30)$ & Young adult (20-25) & $\mathrm{F} ?$ & - & & Alley \\
\hline 19 & No (20) & Old adult & $\mathrm{M}$ & - & & Alley \\
\hline 20 & No (5) & Child (3.5-6.5) & $?$ & - & & Street/alley \\
\hline 21 & No (25) & Adolescent (ca. 12-15) & $?$ & $\begin{array}{l}\text { Partial (carbonization teeth, few cranial fragments, } \\
\text { vertebrae fragments) }\end{array}$ & & Street \\
\hline 22 & No (5) & Child (3.5-6.5) & $?$ & - & & Street \\
\hline 23 & No $(20)$ & Young adult (20-25) & $M ?$ & Partial (carbonization anterior mandibula) & $\mathrm{x}$ & Street \\
\hline 24 & No $(20)$ & Middle adult & M & - & & House 3 \\
\hline 25 & No (5) & Infant (1.5-3 months) & $?$ & - & & House 40 \\
\hline 26 & No (5) & Infant (ca. 2-4 months) & $?$ & - & & House 3 \\
\hline
\end{tabular}


complete femur or humerus is divided into eleven anatomical zones, and each bone fragment is then recorded by the zones present (i.e., available preserved bone). Furthermore, to record degrees of weathering, the six-stage system by Behrensmeyer (1978) was used. Behrensmeyer (1978:151) defines weathering as "the process by which the original microscopic organic and inorganic components of a bone are separated from each other... on the bone in situ, either on the surface or within the soil zone." The six stages describe the process of destruction, from greasy bones (stage 0 ) to surface cracking, flaking, and loose splinters (stages 1-4), to "bone falling apart" (stage 5), for mammals over $5 \mathrm{~kg}$ in body weight (Behrensmeyer 1978:151). Lyman and Fox (1997) have stated that these stages need not have any correlation to time since assemblage formation, but they may nevertheless be seen as stages of the decomposition process. Lyman and Fox (1997:227) also point out that different elements could degrade at different rates, suggesting that only one skeletal element from the same taxon should be used for comparisons. Here, we chose to compare the weathering stages of the preserved human femora and humeri from either (the most complete or only preserved) side for each individual. Furthermore, a fracture analysis was carried out based on the same bone elements, which were assigned a fracture freshness index (FFI) (Outram 2002). The method involves the analysis of three criteria-fracture outline, fracture edge texture, and fracture angle-that are scored 0-2 $(0=$ fresh; $1=$ some unfresh features; $2=$ unfresh). In the current analysis the appearance of the most prominent fracture of each element was scored.

The fourth technique used to trace the perimortem and postmortem fate of the individuals and their surrounding context was the use of archaeothanatology (previously known as anthropologie de terrain). This method was developed in France from the 1970s onward and aims to reconstruct the "chaîne opératoire" of the handling of the dead (Duday 1978, 1987a, 1987b; Duday et al. 1990; Duday and Masset 1987). Archaeothanatological analyses and methodological summaries began to appear in English in the late 1990s (Duday 2006, 2009; Nilsson 1998; Nilsson Stutz 2003; Roksandic 2002). A similar chain of thought had also been described by Wilder and Whipple (1917), called "necrodynamics" (Wilder 1923). Through careful investigation and documentation of skeletal remains in situ, the original position of the cadaver and any subsequent manipulation is deduced. This evaluation requires the separation of external and internal movement of the cadaver, and subsequently the skeleton (e.g., Duday 2009:6-7).

The cadaver and the skeletal remains are affected by both internal and external alterations. Gravity affects the decomposing body, and the position of the cadaver will induce different responses both in terms of the surrounding material and the voids created as the soft tissues decompose (Duday 2006, 2009). Articulation of labile joints indicates a short time span between death and final deposition of the cadaver, whereas persistent joints can articulate for a longer time period. Labile joints include the temporomandibular joint, cervical vertebrae, costosternal joints, scapulothoracic junction, hand bones, and foot phalanges (cf. Duday 2009:27; Nilsson Stutz 2003:152-157, 212). Articulation of all joints is, however, dependent on the surrounding context and climate. Natural mummification can, for example, keep the joints articulated for a long time period, even if the cadaver is moved. If some of the labile joints still articulate, this implies a primary deposit of the dead even if not all joints articulate. The absence of articulated joints does not prove secondary deposit, but it is often the result of disturbances caused, for example, by animals, water, collapsing structures above, or decomposing substrata. Secondary deposits are the result of manipulation of the dead during or following decomposition (see Duday 2009 for detailed descriptions).

If a body decomposes in a void, lateral displacements of bones are expected, as sedimentary support is not provided. Some dislocations of skeletal elements can also be found in filled spaces, as the decomposition of soft tissues allows some movement inside the initial volume of the cadaver. Proposed diagnostic movements of a supine skeleton in a void decomposition are opening of pubic symphysis and sacroiliac joints, allowing ilium to fall posteriorly, and lateral rotation of femoral head from acetabulum and patellar dislocation (e.g., Duday et al. 1990, Duday 2009; Roksandic 2002). Prone, lateral, or sitting body positions will likely produce other movements. The key principle, however, is to look for any movements outside of the initial volume of the cadaver, as they are diagnostic of void decomposition regardless of body position (e.g., Duday 2006, 2009:13-57; Duday et al. 1990; Nilsson Stutz 2003:148-158, 212, 252-270; Roksandic 2002). Microclimate-dependent phenomena, such as natural desiccation, change the resistance of the joints (Duday 2006, 2009:13-57; Duday et al. 1990; Nilsson Stutz 2003:148-158, 212, 252-270; Roksandic 2002).

Disarticulation of labile joints such as those in the hands is to be expected in voids. This disarticulation would imply that the void around the body existed during the early phase of decomposition (Duday 2009:32-38). Recent actualistic studies of disarticulation and bone movement of human remains were conducted at the Forensic Anthropology Center at Texas State University by Mickleburgh and Wescott (2018). The study object was the (willed donated) body of an 
adult female who was seated in a pit that was not filled. The study has, among other things, shed light on the possibility of rearticulation and reconnection of joints that have expanded or disarticulated during the decomposition of soft tissues. Disarticulation of phalanges from hands and feet was also noted as a result of maggot activity. Regarding buried bodies, Duday (2009:54-55) acknowledged the radical alterations of sediment surrounding the cadaver and skeleton caused by maggots. The putrefaction mass created by the cadaver itself during decomposition is extensive and can cause skeletal displacements (Duday 2009:34). The cadaver substrata and the surrounding material interact with the fluids differently. Several internal factors affect the decomposition of the cadaver, such as body mass, manner of death, age, sex, and pathology (Garland and Janaway 1987).

Field anthropological observations in Sandby borg have been made by Alfsdotter and recorded throughout the excavation campaigns since 2014, and detailed archaeothanatological accounts have been made from the field documentation (descriptions, photos, and 3D photogrammetry in GIS). Wilhelmson (2017) conducted the osteological documentation inside house 40 between 2011 and 2013 and an osteological analysis of individuals 1 and 2. An independent reanalysis of these individuals with regard to both osteological observations and context documentation has been carried out subsequently. Since most elements discovered outdoors are solitary finds, they were excluded from the archaeothanatological analysis. In addition, some fragmentary indoor remains were insufficiently preserved to allow thorough archaeothanatological observations. In the taphonomic analysis of each of nine more complete indoor individuals, the following was noted: articulation and disarticulation of joints; skeletal position; type of debris covering the skeleton; skeletal substrata (i.e., soil, stone, animal bones, hearths, etc.); thermal modification; possible traces of clothing details and associated finds. Articulated skeletal elements are considered as units (i.e., body parts). The analysis of the indoor skeletal joint articulation was classified as disarticulation, articulation, or joint disengagement. The latter was used when the bones constituting the joint were still in anatomical order but moderately separated (up to $50 \mathrm{~mm}$ ). All data were documented in a database in the field, through photographs, photogrammetry, and sketches, which were the basis for the interpretations.

Skeletal material from the street areas excavated so far are highly fragmented and disarticulated. Most of the human remains that can be identified are teeth. Small units of bone elements from the same individual were documented outdoors, such as teeth still in occlusion from the same upper and lower jaw (ID21), and several bone fragments that stem from the same cranium (ID18), as evidenced through fitting, were found in a small alley (ca. $1.4 \mathrm{~m}$ wide, Fig. 3). The bones, bone fragments, and teeth in the area derive from at least two different individuals, although not in articulation. Given the lack of articulation of human synovial joints in the outdoor context, archaeothanatological analysis was not applied to outdoor bones. Weathering and fracture analyses were conducted on both indoor and outdoor human remains.

\section{Results}

The general preservation of human remains is poor. The individuals with the best element representation were found inside house 40 (Fig. 5; Table 1).

\section{Root etching and scavenging marks}

Due to the shallow cultural layers and extensive bioturbation, all examined bone fragments showed varying degrees of root etching. Thus, root etching does not differ between contexts. The presence of possible animal bite marks was observed in six elements (Table 2). Four distinct gnawing marks (in three different houses) were identified as caused by rodents. The remaining three possible scavenging marks are vague in character. One of the latter is likely from a canid, but no unambiguous marks from canines have been identified in the material. Thus, postmortem gnawing was either limited in extent or was unidentified in many cases due to poor cortical preservation of bones and/or completely devoured bones.

\section{Thermal modifications}

The remains from a minimum of seven individuals display partial thermal modification, but no complete skeleton is affected. The state of preservation of the skeletons that display thermal modifications vary (Table 1). Of the seven, elements from two individuals (ID21 and ID23) were found outdoors. Their remains were adjacent to house walls. The five skeletons with thermal alterations indoors were discovered in the middle section of house 40 (three individuals), in house 52 (one individual), and in house 4 (one individual). The thermal alterations of the two latter individuals are presumably the result of their bodies being in contact with active hearths (ID9 accounted for below). Four neurocranial fragments belonging to ID5 (house 40) are carbonized. They are brownblack ectocranially and unaffected endocranially. The 


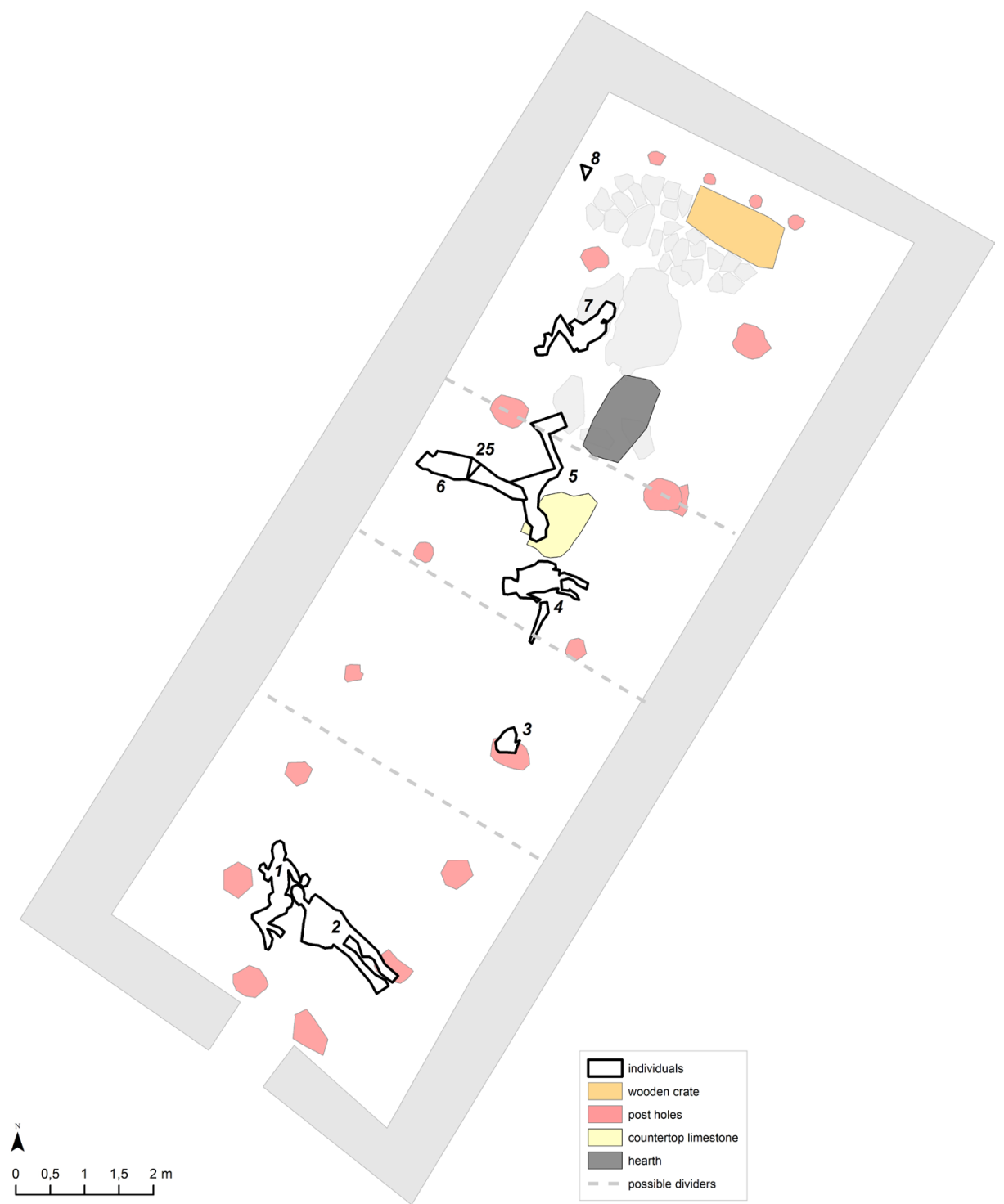

Figure 5. A plan view of human remains belonging to unique individuals recovered in house 40 . (Figure by Helena Victor.)

Table 2. Distribution of bite or gnaw marks in the skeletal material. $\mathrm{F}$ (find number) is used when the bone element cannot be established to constitute part of a unique individual.

\begin{tabular}{lllll}
\hline ID & Gnawing & Element & Cause & Context \\
\hline F8475 & Possibly & Tibia & ? & Street \\
ID 2 & X & Humerus & Rodent & House 40 \\
ID 13 & X & Humerus & Rodent & House 4 \\
ID 13 & X & Tibia & Rodent & House 4 \\
F9349 & Possibly & Long bone & Rodent & Street \\
F6874 & Possibly & Scapula & Carnivore & House 40 \\
ID9 & X & Femur & Rodent & House 52 \\
\hline
\end{tabular}

fragments display delamination, indicative of perimortem thermal alteration (e.g., Bontrager and Nawrocki 2015). In addition, small fragments from ribs and one lumbar vertebral spinous process are carbonized apart from the latter with localized calcination (stage 4 after Stiner et al. 1995). The thermal alterations are from regions that have limited soft tissue shielding. The skeleton is poorly preserved, and only fragments of the upper body remain.

ID3 (house 40) displays four partially carbonized teeth, incisors and canines (whereas the teeth that are located distally are unaffected). The crowns are fragmented and the enamel splintered. The cementoenamel junction (CEJ) is carbonized, and the apical part of the root appears unaltered. A few rib fragments display partial carbonization. The neurocranial fragments are not affected by fire. This pattern indicates a limited exposure to fire, where a few of the superficial bone and tooth elements have been affected to a mild degree. 

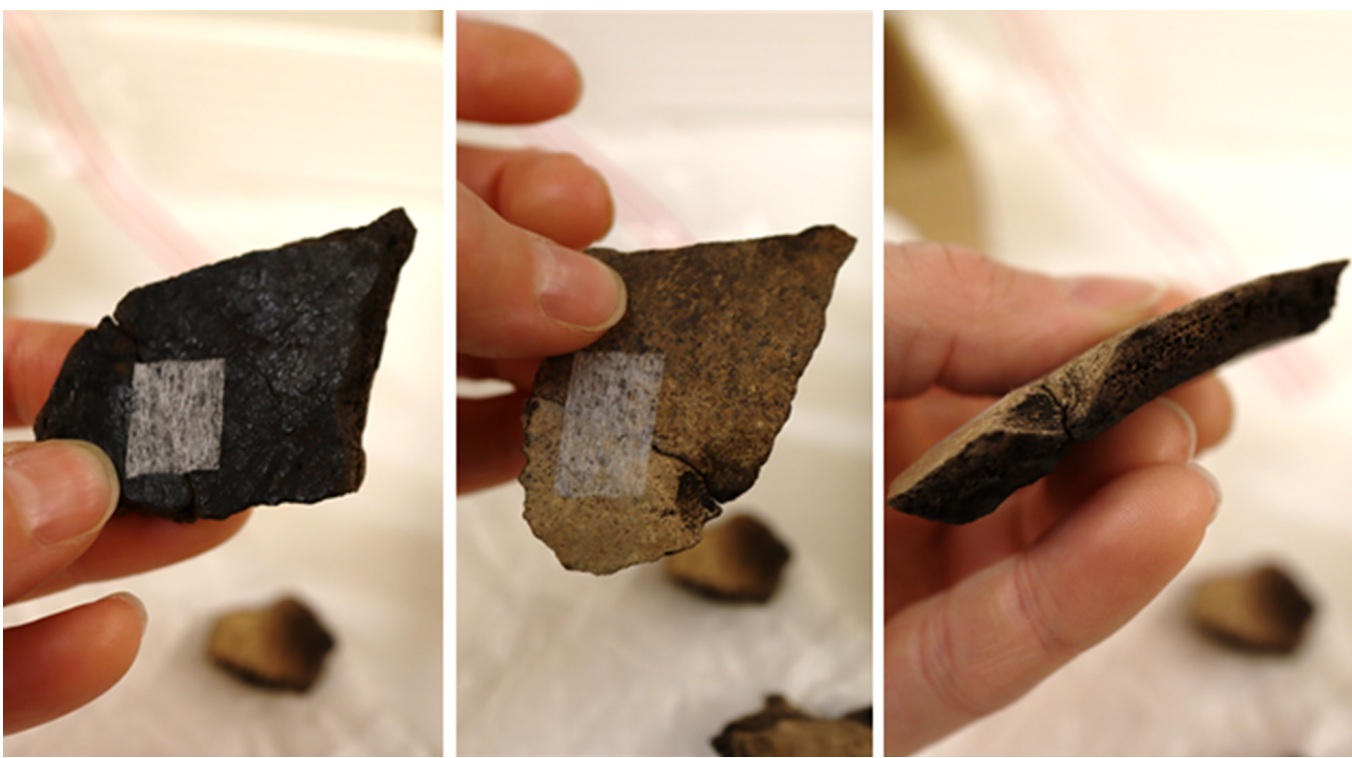

Figure 6. Several calvarium fragments are unaffected exteriorly but carbonized interiorly, which is an indication of the pooling of liquefied soft tissue inside the cranium (e.g., Schmidt et al. 2015). Fragments from F6671 are pictured, from left to right: internal table, external table, and lateral view of the diploë (the spongy cancellous bone between the tabulae).

ID4 (house 40) displays a carbonized mandibular condyle (left) and a few partially carbonized cranial fragments. Some of the latter are unaffected ectocranially and uniformly carbonized endocranially (see Fig. 6). This condition is probably the result of "pooling" of liquefied soft tissue due to the internal heat and pressure, thus suggestive of perimortem thermal alteration (Schmidt et al. 2015). Perimortem sharp force trauma is visible on fragments from the cranium (right occipital) that do not display the visible thermal changes of ID4.

Additional thermally altered cranial fragments (F6141 and F6671), some with fitting, were found in the same area as ID5 and ID4 (possibly belonging to either). Several fragments are consistent with the internal pooling and unaffected external surface as visible on some cranial fragments from ID4. The external table of other fragments show "localized" burning or are "half calcined" in accordance with stage 4 in the scale by Stiner et al. (1995), except for some fracture lines where the bone is only carbonized, supposedly the result of soft tissue liquids protecting the fractures through which they escaped from the most intense heat (Fig. 7) (Symes et al. 2015).

The thermal alterations of several of the skeletons are consistent with perimortem changes (i.e., human remains with soft tissue still present). The question is, then, whether the fire preceded the death of the individuals; if fire was the manner of death, or occurred following death? These queries are not necessarily warranted, given that none of the bodies (or even skulls) are affected as wholes, nor do we see any indications

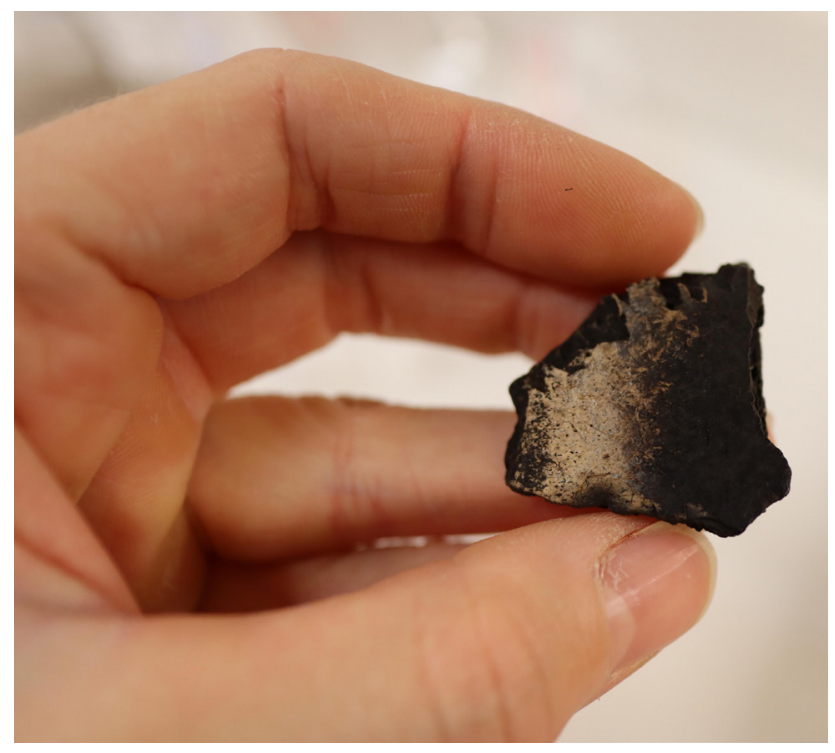

Figure 7. The heterogeneous thermal patterning can be the result of soft tissue liquid protecting fracture lines from the most intense heat (Symes et al. 2015). A fragment from F6141 is pictured.

of "pugilistic" body positions (the result of muscle fibers contracting as a result of exposure to high heat) (DeHaan 2015; Symes et al. 2015). In addition, the cranium of ID4 displays sharp force lesions, giving an indication of the manner of death. If interpersonal trauma preceded the burning, then it is likely that the carbonized fracture lines might be secondary fractures from traumatic lesions (the identified sharp force lesion itself is unaffected by fire). It is also possible that the perimortem fractures were in some cases caused by 
heat; however, as Schmidt et al. (2015) describe, the intracranial pressure and liquid will escape through openings in the cranium; if such openings were induced prior to fire, it is likely that the development of additional thermal fractures would have been reduced.

The sequence of events presented here does not support a scenario where individuals were burned alive. The taphonomic observations favor the interpretation that limited fire modifications affected the bodies shortly after death. Additional thermal alterations without diagnostic value are presented in Table 1. In general, the affected bones are few, mainly carbonized, and the lesions are from regions with limited soft tissue shielding.

Preservation, degrees of weathering, and fracture analysis

Table 3 presents results from the taphonomic investigation of femora and humeri. Femora from 11 individuals and humeri from 14 individuals were examined. Although the sample size is small, some differences in preservation can be traced. Looking at the zones present for each femoral element, the bones from the indoor environment demonstrate more complete elements than those encountered outdoors. However, the femoral weathering scores are not greatly different between the street and the houses, and the FFI shows the same degree for indoor and outdoor femora
(Tables 3 and 4). The humeri show a similar pattern; while the elements are better preserved indoors as demonstrated through the presence of zones, the weathering scores and FFI are roughly the same between the two contexts (Tables 3 and 4). In fact, the FFI demonstrates worse preservation indoors.

\section{Skeletal disarticulation and articulation inside houses}

The taphonomy varies widely within the completely excavated houses; in some cases, disarticulation patterns even appear to differ in the same skeleton, as demonstrated in the summarized archaeothanatological analysis presented in Tables 5 and 6. Half of the individuals found indoors were largely in anatomical arrangement. Eight of nine exhibited clear signs of primary deposits of the body, and the ninth indicated a probable primary deposit (Table 5). The skeletal positions varied, with the analysis showing that five of nine skeletons had decomposed in voids and the remaining four suggest probable void decomposition (Table 6). The individuals were found on the tread level of the houses, consistent with the interpretation of decomposition in open space. In some cases, void decomposition and primary deposits are evidenced through the interaction of the skeletons. For instance, ID6 shows minimal movement outside of the initial volume of the cadaver (aside from some smaller bones

Table 3. Femora and humeri preservation according to the zone system (Knüsel and Outram 2004), weathering (Behrensmeyer 1978), and FFI (Outram 2002). L = left, R = right, PUF = proximal epiphysis unfused, DUF = distal epiphysis unfused.

\begin{tabular}{|c|c|c|c|c|c|c|c|c|}
\hline \multirow[b]{2}{*}{ ID } & \multirow[b]{2}{*}{ Element } & \multirow[b]{2}{*}{ Zones } & \multirow[b]{2}{*}{ Weathering } & \multicolumn{3}{|c|}{ Criteria for FFI } & \multirow[b]{2}{*}{ FFI } & \multirow[b]{2}{*}{ Context } \\
\hline & & & & Outline & Angle & Surface & & \\
\hline F8256 & Femur, ? & 6 & 3 & 2 & 2 & 2 & 6 & Street \\
\hline ID16 (8833) & Femur, L & 6 & 2 & 2 & 2 & 2 & 6 & Street \\
\hline ID15 (8834) & Femur, L & $1,2,3,4,5,6,7,8,9,10,11$ & 2 & 1 & 2 & 2 & 5 & House 4 \\
\hline ID8762 & Femur, R & $1,2,3,4,5,6,7,8$ & 2 & 1 & 1 & 2 & 4 & House 4 \\
\hline ID4 & Femur, L & 6 & 5 & 2 & 2 & 2 & 6 & House 40 \\
\hline ID7 & Femur, L & $1,2,3,5,6,7,8$ PUF, DUF & 1 & 2 & 2 & 2 & 6 & House 40 \\
\hline ID2 & Femur, L & $1,2,3,4,5,6,7,8,9,10,11$ & 1 & 2 & 2 & 2 & 6 & House 40 \\
\hline ID5 & Femur, L & $2,3,6,7,9$ & 2 & 2 & 2 & 2 & 6 & House 40 \\
\hline ID6 & Femur, L & $1,2,3,4,5,6,7,8,9,10,11$ PUF, DUF & 2 & 2 & 2 & 2 & 6 & House 40 \\
\hline ID1 & Femur, R & $1,2,3,4,5,6,7,8,9$ & 1 & 1 & 2 & 2 & 5 & House 40 \\
\hline 4528 & Femur, R & $1,2,3,4,5,6,7,8,9,10,11$ & 1 & 2 & 2 & 2 & 6 & House 52 \\
\hline ID21 (F8402) & Humerus, L & $2,9,10$ & 1 & 0 & 2 & 2 & 4 & Street \\
\hline ID19 (F8890) & Humerus, L & $7,8,9,10$ & 1 & 1 & 2 & 1 & 4 & Street \\
\hline F9346 & Humerus, R & $4,7,8$ & 2 & 2 & 2 & 2 & 6 & Street \\
\hline F8126 & Humerus, R & 7,8 & 2 & 2 & 1 & 2 & 2 & Street \\
\hline ID15 (F8834) & Humerus, R & $3,7,8,9,10,11$ & 2 & 2 & 2 & 2 & 6 & House 4 \\
\hline F6669 & Humerus R & $2,7,8,9,10,11$ & 3 & 2 & 2 & 2 & 6 & House 40 \\
\hline ID7 & Humerus, L & $2,7,8,9,10,11$, PUF & 1 & 1 & 2 & 2 & 5 & House 40 \\
\hline ID3 & Humerus, L & 10 & 2 & 2 & 2 & 2 & 6 & House 40 \\
\hline ID6 & Humerus, L & $1,2,3,4,5,6,7,8,9,10,11$ PUF, DUF & 1 & 2 & 2 & 2 & 6 & House 40 \\
\hline ID4 & Humerus, R & $3,4,5,6,7,8,9,10$ & 2 & 0 & 1 & 2 & 3 & House 40 \\
\hline ID1 & Humerus, R & $3,4,5,6,7,8,9,10$ & 1 & 2 & 2 & 2 & 6 & House 40 \\
\hline ID2 & Humerus, R & $5,6,7,8,9,10,11$ & 1 & 2 & 2 & 2 & 6 & House 40 \\
\hline ID5 & Humerus, R & $7,8,9,10,11$ & 3 & 2 & 2 & 2 & 6 & House 40 \\
\hline F4528 & Humerus, R & $1,2,3,4,5,6,7,8,9,10,11$ & 1 & 0 & 1 & 2 & 3 & House 52 \\
\hline
\end{tabular}


Table 4. Mean, mode, and median weathering and FFI scores for individuals found inside and outside houses.

\begin{tabular}{lrccc}
\hline & $N$ & Mean & Mode & Median \\
\hline $\begin{array}{l}\text { Weathering: Femur } \\
\text { Street }\end{array}$ & 2 & 2.5 & - & 2.5 \\
Houses & 9 & 1.9 & 2 & 2 \\
FFI: Femur & & & & \\
Street & 2 & 6.0 & 6 & 6 \\
Houses & 9 & 5.6 & 6 & 6 \\
$\begin{array}{l}\text { Weathering: Humerus } \\
\text { Street }\end{array}$ & 4 & 1.5 & 1 & \\
Houses & 10 & 1.7 & 1 & 1.5 \\
FFI: Humerus & & & & \\
Street & 4 & 4.0 & 4 & 4 \\
Houses & 10 & 5.3 & 6 & 6 \\
\hline
\end{tabular}

missing), but the tarsal bones of the left foot were found on top of the pelvis of skeleton ID5. Hand bones from ID5 were found underneath the left fibula of ID6. This shows us the course of events, where ID5 was lying on the floor when ID6 ended up in the position in which decomposition subsequently took place. ID6 shows articulation of labile joints, diagnostic of primary deposits. In contrast, ID5 shows extensive disarticulation outside of the initial volume of the cadaver, indicative of void decomposition (Duday 2009:32-38). The spatial relationship between the individuals indicates that both individuals decomposed in a void and that the deposits were primary.

The skeleton of an old adult male, ID9 (house 52), exhibits several features important for the understanding of his postmortem condition. ID9 was found prone and extended across a stone-enclosed hearth (Fig. 8). The lower limbs were crossed, with the feet presenting their plantar side. The mandible, thorax, and parts of the upper extremities rested on stones enclosing the hearth, and the feet on another. The skeleton was highly fragmented, but several joints were still in articulation. Some bones were displaced, and several elements missing. The cranium, six cervical vertebrae, the left clavicle, left scapula, left humerus and all the left wrist and hand bones, along with the right trapezoid, were missing. The left radius and ulna were present, however. Some cranial fragments that might have belonged to the man were found farther into the house. The cranial fragments are from an adult, and ID9 is the only adult skeleton encountered inside house 52, apart from a lower jaw that was found in a (burrowing animal?) pit, discussed in more detail below.

The partial carbonization of ID9 (right ilium, right ischium, posterior parts of the sacrum, and three rib fragments) bears witness to the hearth being active as the body fell over it (presumably when the man was unconscious or dead). The body was not ravaged by fire; only small areas of superficial bones adjacent to the center of the hearth have been partly carbonized to stages 1-2 (Stiner et al. 1995). Carbonized areas of bone have been in direct contact with flame or intense heat according to Herrmann (1977) and Symes et al. (2015:40). The meager modifications suggest that surrounding unaffected bone was still protected by soft tissue when the fire eventually died (e.g., Schmidt et al. 2015). The thermal alteration, in combination with

Table 5. Nature of deposit. Articulation of labile joints are diagnostic of a primary deposit of the cadaver (e.g., Nilsson Stutz 2003:212, discussed in Supplement 2). Articulated joints are marked with A, even if only unilateral articulation. Disarticulated joints are marked with DA. M is short for "missing." U is short for "unobservable." X in bloat column indicates occurrence.

\begin{tabular}{|c|c|c|c|c|c|c|c|c|c|}
\hline ID & $\begin{array}{l}\text { Cervical } \\
\text { Vertebrae } \\
2-7\end{array}$ & $\begin{array}{l}\text { Carpal } \\
\text { Bones }\end{array}$ & $\begin{array}{c}\text { Tarsal } \\
\text { Phalanges }\end{array}$ & $\begin{array}{l}\text { Costosternal } \\
\text { Joints }\end{array}$ & $\begin{array}{l}\text { Scapulathoracic } \\
\text { Junction }\end{array}$ & $\begin{array}{l}\text { Temporo- } \\
\text { mandibular } \\
\text { Joint }\end{array}$ & $\begin{array}{l}\text { Indications of } \\
\text { Bloat (abduction } \\
\text { of upper limbs) }\end{array}$ & Comments & $\begin{array}{c}\text { Nature of } \\
\text { Deposit }\end{array}$ \\
\hline 1 & $\mathrm{~A}$ & $\mathrm{DA}$ & $\mathrm{A}$ & $\mathrm{U}$ & $\mathrm{U}$ & $\mathrm{U}$ & Possibly & & Primary \\
\hline 2 & $\mathrm{~A}$ & A & $\mathrm{DA}$ & $\mathrm{U}$ & A & $\mathrm{U}$ & $\mathrm{X}$ & & \\
\hline 4 & $\mathrm{U}$ & A & M & $\mathrm{U}$ & $\mathrm{A}$ & $\mathrm{U}$ & $\begin{array}{l}\text { Possibly right } \\
\text { upper limb }\end{array}$ & Highly fragmented. & Primary \\
\hline 5 & $\mathrm{U}$ & A & $\mathrm{U}$ & M & $\mathrm{U}$ & $\mathrm{U}$ & - & $\begin{array}{l}\text { Highly fragmented. } \\
\text { Hand bones } \\
\text { underneath ID6. }\end{array}$ & Primary \\
\hline 6 & A & $\begin{array}{c}\mathrm{A} \\
(\text { partial})\end{array}$ & M & $\mathrm{DA}$ & A & $\mathrm{U}$ & - & $\begin{array}{l}\text { Fragmented skull } \\
\text { (cranium and } \\
\text { mandibula). Tarsal } \\
\text { bones on top of ID5. }\end{array}$ & Primary \\
\hline 7 & A & $\mathrm{U}$ & $\mathrm{A}$ & M & A & A & - & & Primary \\
\hline 9 & $\begin{array}{l}M \text { (but } \\
\text { for C7) }\end{array}$ & $\mathrm{DA}$ & A & $\mathrm{U}$ & A & M & $\begin{array}{l}\text { Possibly left } \\
\text { upper limb. }\end{array}$ & $\begin{array}{l}\text { Thermal trauma } \\
\text { indicates primary } \\
\text { deposit of body in } \\
\text { hearth. }\end{array}$ & Primary \\
\hline 12 & A & $\mathrm{DA}$ & M & M & $\mathrm{A}$ & $\mathrm{A}$ & $\mathrm{X}$ & Verticalized clavicles. & Primary \\
\hline 15 & $\mathrm{DA}+\mathrm{M}$ & $\mathrm{DA}$ & DA & $\mathrm{DA}$ & $\mathrm{DA}$ & A & - & $\begin{array}{l}\text { Heavy disarticulation } \\
\text { of upper body. }\end{array}$ & Primary? \\
\hline
\end{tabular}


Table 6. Space of deposit. Note that expected lateralization of patellae, femora, and ossa coxae are presumed diagnostic of a supine extended body position. Prone or lateral body positions will produce other movements. Movements outside of the initial volume of the cadaver regardless of body position are expected if the body decomposed in a void (cf. Duday 2009:32-38). X indicates that the change was noted bilaterally. 1 indicates a unilateral occurrence. Joint disengagement is marked JD (see methods). M indicates "missing." U indicates "unobservable."

\begin{tabular}{|c|c|c|c|c|c|c|c|c|c|}
\hline ID & Body Position & $\begin{array}{c}\text { Iliac } \\
\text { Lateralization }\end{array}$ & $\begin{array}{l}\text { Opening } \\
\text { of Pubic } \\
\text { Symphysis }\end{array}$ & $\begin{array}{c}\text { Femoral } \\
\text { Lateralization }\end{array}$ & $\begin{array}{l}\text { Patellar } \\
\text { Dislocation }\end{array}$ & $\begin{array}{l}\text { Other } \\
\text { Movements } \\
\text { outside of } \\
\text { Initial } \\
\text { Movement of } \\
\text { Cadaver. }\end{array}$ & $\begin{array}{l}\text { Indications } \\
\text { of Bloat } \\
\text { (abduction } \\
\text { of upper } \\
\text { limbs) }\end{array}$ & Comments & $\begin{array}{l}\text { Space of } \\
\text { Deposit }\end{array}$ \\
\hline 1 & $\begin{array}{l}\text { Supine, lower } \\
\text { limbs flexed. }\end{array}$ & ID & - & - & - & $\begin{array}{l}\text { Upper limbs } \\
\text { disarticulated } \\
\text { but for } \\
\text { proximal left } \\
\text { humerus. } \\
\text { Right radius } \\
\text { on left femur. }\end{array}$ & $\begin{array}{l}\text { Possibly } \\
\text { upper limbs }\end{array}$ & & Void? \\
\hline 2 & $\begin{array}{l}\text { Prone extended. } \\
\text { Left upper limb } \\
\text { flexed and } \\
\text { abducted. }\end{array}$ & - & - & $\mathrm{JD}(1)$ & $\mathrm{U}$ & - & $\begin{array}{l}\text { Left upper } \\
\text { limb }\end{array}$ & & Void \\
\hline 4 & $\begin{array}{l}\text { Prone. Extended } \\
\text { limbs apart from } \\
\text { flexed upper limb. }\end{array}$ & $\mathrm{U}$ & - & - & M & $\begin{array}{l}\text { Crushed } \\
\text { scattered } \\
\text { cranium, } \\
\text { dislocated } \\
\text { distal left } \\
\text { femur, skeletal } \\
\text { elements } \\
\text { distally of } \\
\text { femora } \\
\text { missing. }\end{array}$ & $\begin{array}{l}\text { Possibly } \\
\text { right upper } \\
\text { limb }\end{array}$ & $\begin{array}{l}\text { Highly } \\
\text { fragmented. } \\
\text { Crushed bones } \\
\text { indicate high } \\
\text { external } \\
\text { pressure. Body } \\
\text { position not } \\
\text { typical for } \\
\text { burial. }\end{array}$ & Void? \\
\hline 5 & $\begin{array}{l}\text { Supine with } \\
\text { partial rotation. } \\
\text { Flexed left upper } \\
\text { limb and lower } \\
\text { limbs. Missing } \\
\text { right upper limb. }\end{array}$ & $\mathrm{U}$ & $\mathrm{U}$ & $\mathrm{X}$ & M & $\mathrm{X}$ & - & $\begin{array}{l}\text { Highly } \\
\text { fragmented. } \\
\text { Hand bones } \\
\text { under ID6. }\end{array}$ & Void \\
\hline 6 & $\begin{array}{l}\text { Supine. Extended } \\
\text { limbs. }\end{array}$ & 1 & - & - & M & - & - & $\begin{array}{l}\text { Left tarsal } \\
\text { bones on top } \\
\text { of ID5. }\end{array}$ & Void? \\
\hline 7 & $\begin{array}{l}\text { Lateral/supine. All } \\
\text { limbs flexed, lower } \\
\text { extremities more } \\
\text { prominently so. }\end{array}$ & $\mathrm{X}$ & - & 1 & 1 & $\begin{array}{l}\text { The few } \\
\text { recovered } \\
\text { hand bones } \\
\text { have fallen in } \\
\text { favour of } \\
\text { equilibrium. }\end{array}$ & - & $\begin{array}{l}\text { Right knee } \\
\text { aligned } \\
\text { towards stone. } \\
\text { Patella in } \\
\text { place. }\end{array}$ & Void \\
\hline 9 & $\begin{array}{l}\text { Prone extended } \\
\text { with crossed } \\
\text { lower limbs. }\end{array}$ & - & $\mathrm{U}$ & - & - & $\begin{array}{l}\text { Several bones } \\
\text { missing, some } \\
\text { hand bones } \\
\text { have fallen } \\
\text { into void. }\end{array}$ & $\begin{array}{l}\text { Possibly left } \\
\text { upper limb. }\end{array}$ & $\begin{array}{l}\text { Parts of body } \\
\text { have sunken } \\
\text { into the fill of } \\
\text { hearth. High } \\
\text { fragmenta- } \\
\text { tion. Patellar } \\
\text { articulation. }\end{array}$ & Void \\
\hline 12 & $\begin{array}{l}\text { Supine, slightly } \\
\text { rotated thorax. } \\
\text { Verticalized } \\
\text { clavicles. Large } \\
\text { parts of lower } \\
\text { limbs missing. }\end{array}$ & M & M & 1 & M & $\begin{array}{l}\text { Several bones } \\
\text { missing. }\end{array}$ & $\begin{array}{l}\text { Possibly left } \\
\text { upper limb. }\end{array}$ & $\begin{array}{l}\text { Large parts of } \\
\text { skeleton } \\
\text { missing. } \\
\text { Present } \\
\text { elements } \\
\text { show } \\
\text { articulation. }\end{array}$ & Void? \\
\hline 15 & $\begin{array}{l}\text { Right lower limb } \\
\text { tightly flexed, left } \\
\text { lower limb } \\
\text { partially } \\
\text { disarticulated. } \\
\text { All of upper body } \\
\text { scattered. }\end{array}$ & - & M & $\mathrm{JD}(1)$ & M & $\begin{array}{l}\text { Scattered } \\
\text { upper body } \\
\text { and left femur. } \\
\text { Several bones } \\
\text { missing. }\end{array}$ & - & & Void \\
\hline
\end{tabular}




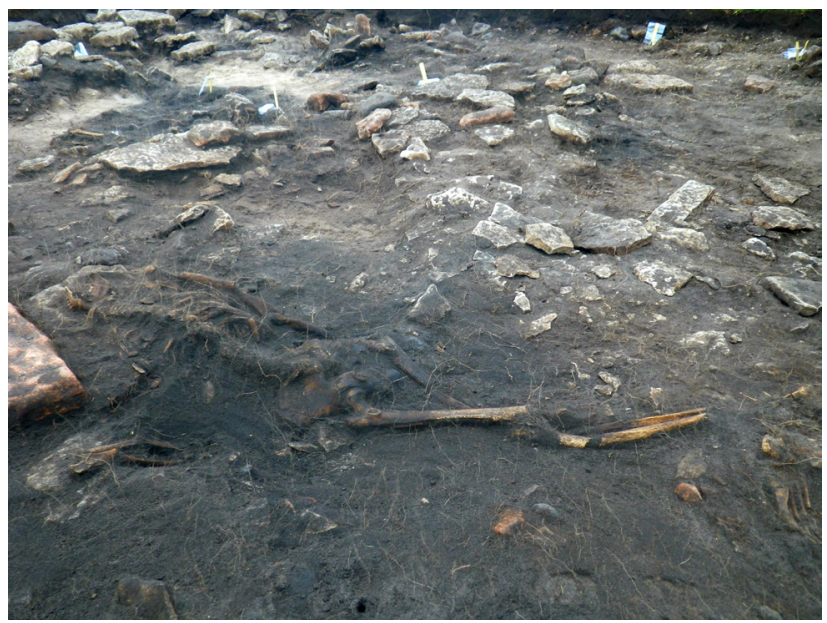

Figure 8. ID9 was found lying across the central hearth of house 52. The carbonization of parts of the hip bear evidence of the fire being active when the male individual fell over it at the time of death. The skeleton was in a prone position with lower limbs crossed. The vast majority of the cranium was missing. Note the still-articulated metatarsals and first phalanges in the bottom right corner of the picture. (Photo courtesy of the Kalmar County Museum.)

the position of the skeleton across the fireplace, and some still-articulated labile joints (Table 5), suggests a primary deposit of the body. The displacement of several skeletal elements outside of the initial volume of the cadaver indicates that the body decomposed in a void (Table 6). Skeletal elements resting on top of the stones surrounding the hearth are highly fragmented due to external pressure. The latter is also true for some elements inside the hearth, such as the right radius and ulna that display dry bone fractures, likely the result of a small (falling) stone (found in situ) that had pushed the central-distal diaphysis downward. Dry bone fractures and displacements are seemingly partly the result of falling house debris, as the skeleton was found under the demolition layer of the house. This case illustrates how the postmortem process can be traced in the unusual non-burial, but in part protected, indoors context in terms of timing.

\section{Discussion}

The individuals recovered from the street are all represented by single disarticulated elements or bone units. Given the contextual circumstances, the poor preservation, high degrees of weathering, and many dry breaks were expected among these elements. The humeri and femora that could be included in the analyses are likely just a portion of the original long bones in the street, as splinters of long bone diaphysis that cannot be identified are frequent. Thus, the comparison between indoor and outdoor skeletal remains should be interpreted with caution. The humeri and femora that could be identified show that the remains found in the street experienced similar weathering effects to those found within the houses. This observation implies that, although the elements on the street were severely scattered and broken, similar processes affected both contexts. However, the comparative study is weakened by the uneven spatial distribution, since 19 of the 25 bones taken into account (humeri and femora) were discovered inside the houses and only nine outside.

As illustrated through the archaeothanatological (Table 5 and 6) and stratigraphic observations, the majority of the skeletons encountered indoors show evidence that the bodies were left in their primary location (as previously proposed for ID1 and ID2 by Wilhelmson and Dell'Unto 2015), decomposing in voids. This pattern is confirmed in all houses excavated, where the skeletons were found to be partially disarticulated. Disequilibrium has allowed parts of skeletons to fall into voids when soft tissues decomposed. Movement of the bones outside of the initial volume of the cadaver is frequent, as expected for void decomposition. If clothing was worn, the fabric might have helped keep the human remains shielded initially. Fabric helps drain moisture from the cadaver, which might favor both skeletal arrangement and desiccation (e.g., Boquin et al. 2013). However, the movement of skeletal remains outside of the initial space of the cadaver suggests that desiccation of bodies was limited (or absent). The weathering pattern suggests that bones were not covered by sediment initially (Tables 2 and 3). These results contrast with some of the hypotheses previously put forward (based on ID1 and ID2) by Wilhelmson (2017:140); it cannot be supported that the house roofs were deliberately torn down by visitors while the bodies were still decomposing, based on symmetrical long bone fractures supposedly caused by roof beams. If the roof collapsed on the rotting cadavers, we would expect perimortem fractures, given that the organic components of the bones would still have been preserved. Instead, the present analysis suggests that the long bone fractures occurred in dry bone (hence, there are no elements with clear perimortem breaks that can be related to non-human agents).

The prevalence of dry bone fractures due to external pressure is high, showing that house collapse took place after skeletonization (Table 3). Wilhelmson and Dell'Unto (2015) acknowledge that the human skeletal fractures analyzed in their virtual taphonomy study were produced postmortem. They integrated 3D GIS and taphonomic analyses and proposed that the skeletal fractures of ID1 and ID2 (the skeletons included in their study) might be the result of house 
demolition, given the symmetric distribution of the fractures. However, this observation does not correspond with the hypothesis put forward by Wilhelmson (2017:140), where she argued that the house demolition (and thus the fracture pattern that presumably resulted from it) took place before skeletonization. Similarly, the fracture pattern of the ribs of ID1 is interpreted as a result of pressure applied to the thorax during early decomposition, while the sternocostal joints were still held together by soft tissue (Wilhelmson and Dell'Unto 2015). However, the rib fractures are dry bone fractures, which indicate a late stage of decomposition when the organic components were degraded to a great extent. The argument behind early decomposition fracturing is Wilhelmson's observation that the ribs are still in articulated position sternally and that the breaks have occurred midshaft (Wilhelmson and Dell'Unto 2015). As the fracture freshness analysis presented here suggests, this criterion is insufficient for demonstrating fracture during early decomposition.

The suggestion that the bodies were manipulated postmortem, as indicated by the involvement of a bone shaft from a third individual (Wilhelmson and Dell'Unto 2015), is not confirmed in the present study. Reanalysis of the material shows that the bone in question is in fact not an ulnar diaphysis (as proposed by Wilhelmson and Dell'Unto 2015) but from a right radius. The bone fragment was found adjacent to the left femur of ID1. The same individual lacks radii bilaterally, which makes it likely that the shaft originates from ID1 (seen in Fig. 10c). The present archaeothanatological analysis does not support the previous hypothesis regarding postmortem manipulation after the decomposition of soft tissues. The bodies were seemingly left where they fell.

It can also be discussed whether the extensive compression of the floor described in Wilhelmson and Dell'Unto (2015) is supported. This argument builds on the elevated thorax and parts of the upper extremities of ID1 (seen in Fig. 11d), and the right ankle of the same skeleton. The elevated position of the upper body is due to its lying on top of a stone walkway leading from the entrance of house 40 , and the elevation of the right ankle is due to its location on top of the stone hem of a roof-supporting posthole. Elevation of these elements was interpreted as depression of the ambient floor, but we cannot say with any certainty that the walkway and support for the post were aligned with the original floor level.

\section{Deviations from anticipated changes}

Archaeothanatological indicators are based on comparative taphonomic analysis of interred human remains; thus, Sandby borg offers a novel opportunity to expand the method's application. The archaeothanatological principles are based on repeated archaeological observation and should be used with caution. It has not been proved that joints that are persistent in life are persistent in death, and the presumed disarticulation sequence of joints has been questioned (e.g., Appleby 2016; Mickleburgh and Wescott 2018; Peressinotto 2007).

The present study proposes that the Sandby borg skeletons decomposed in voids (Table 6). However, the skeletons in the Sandby borg dwellings do not display all anticipated changes that are presumed for void decomposition, namely, slumping and splaying of the ribcage, splaying of the pelvic girdle, and lateralization and rotation of the femoral heads (from the acetabulum) (e.g., Duday 2009:32-38; Nilsson Stutz 2003: 252-270; Roksandic 2002). Joint disengagements (see methods) are noted in the sacroiliac joint and the pubic symphysis in some cases in Sandby borg, but the typical pattern is not confirmed in the material (Table 6). The atypical disarticulation could in some instances be explained by diverging body positions in Sandby borg from those commonly encountered in graves. Few individuals are extended in a supine position. However, the supine skeletons that can be observed show less disengagement than the criteria suggested, which begs the question why the joints that commonly disarticulate in void burials have not disarticulated in several of the Sandby borg skeletons. ID6, the only fully extended skeleton in a supine position, does not show separation of the pubic symphysis, femoral lateralization, or splaying of ribs (Fig. 10b). The patellae are missing, however, and slight joint disengagement in the sacroiliac joint was observed.

Our results indicate that there is a difference between the skeletons left in the Sandby borg dwellings and "normal" archaeological remains. We suggest that the deviation can possibly be explained by looking at the putrefaction process. Most commonly encountered void decompositions found archaeologically are the result of burials in coffins or other fixed containers, whereas in Sandby borg the bodies were left to decompose on house floors or in the open street (i.e., not a confined space). As the vast majority of archaeothanatological observations are made on interments, the confined volume is the baseline for understanding of the void decomposition pattern. A coffin or other enclosed space would presumably not, if tightly constructed, allow draft or drainage to the same extent as a floor placement would. The splaying often observed in (confined) void decompositions might in some instances be the effect of initial disarticulation during partial submersion caused by 


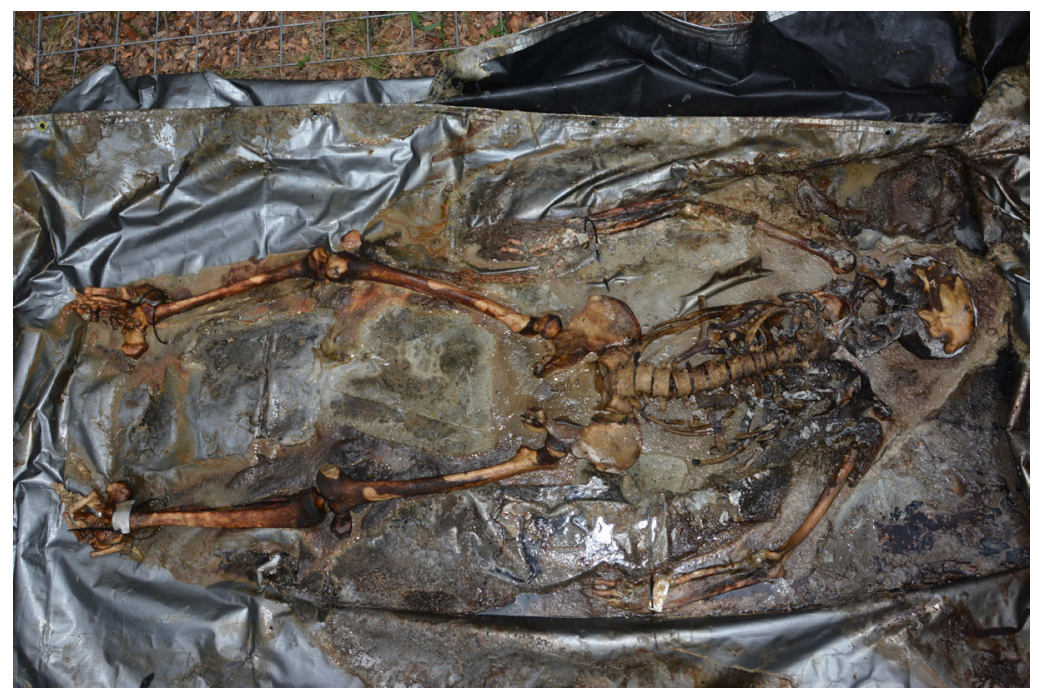

Figure 9. A body placed in a supine position decomposed inside a wrapped tarp. The putrefaction liquids partially submerged the body during decomposition. The disarticulation pattern is similar to the archaeothanatological criteria for void decompositions: slumping and splaying of the ribcage, splaying of the pelvic girdle, lateralization and rotation of the femoral heads, and displacement of the patellae. (Photo courtesy of the Forensic Anthropology Center at Texas State.)

putrefaction liquids or groundwater. This effect was observed at the Forensic Anthropology Center at Texas State (FACTS) by one of the authors (CA). A willed donated cadaver had been placed in a supine extended position and loosely wrapped in a tarp. During decomposition, the cadaver was partially submerged in decomposition liquid, seemingly allowing bones to move and lateralize to a rather large extent (Fig. 9). The disarticulation displayed the pattern expected in voids according to the archaeothanatological literature (more experiments are needed where plastic is exchanged for organic material). Some of the observed skeletons from cadavers that decomposed outdoors at FACTS (in wire cages protecting them from predators) displayed a disarticulation similar to the Sandby borg skeletons, with modest disengagements in the pelvic girdle, femoral heads still in the acetabulum, and ribs in anatomical order (Fig. 10a, b, and c). Our preliminary suggestion is that the limited lateralization of the Sandby borg skeletons might be due to better drainage in an unconfined void. If valid, that would imply that the archaeothanatological criteria observed in archaeological confined void burials might be the result of partial submersion (and/or water level fluctuations) and not the result of gravity alone. To test this hypothesis, the effects of both putrefaction liquids and microclimate factors, such as wind, need to be considered (Alfsdotter forthcoming).

Additional postmortem information can be drawn from the case of ID2, a young male whose remains were found close to the entrance of house 40 . He was lying extended in a prone position (Fig. 11d). The left upper extremity was abducted and the right upper extremity slightly so. This position corresponds well with a body undergoing bloat without sedimentary support (as observed at FACTS, Figs. 11a, b, and c). The limbs are allowed to move freely as the cadaver expands, unlike inside a filled grave. Bloat can thus cause changes of original limb positions (Roksandic 2002). The body position of ID2 further indicates a void decomposition after primary deposition of the body. This observation suggests that the duration of exposure and drainage of putrefaction liquids in void decompositions may have distinctive skeletal-position signatures in coffins versus more open deposits, such as those encountered at Sandby borg. A variety of actualistic studies that evaluate archaeothanatological principles in different settings are needed in order to evaluate the framework and the current hypothesis (see Alfsdotter forthcoming; Mickleburgh 2018; Mickleburgh and Wescott 2018).

Apart from the lack of sedimentary support during decomposition in Sandby borg, the archaeological stratigraphy further strengthens the hypothesis of unburied bodies. Stones from house and ringfort wall demolition were in several cases encountered right on top of skeletons (thus implying lack of preexisting sedimentary support) (Fig. 12). The variation between fragmentation and articulation of skeletons within the same house is partially the result of different substrata. The bodies that decomposed on top of stone paving were severely fragmented and compressed between 

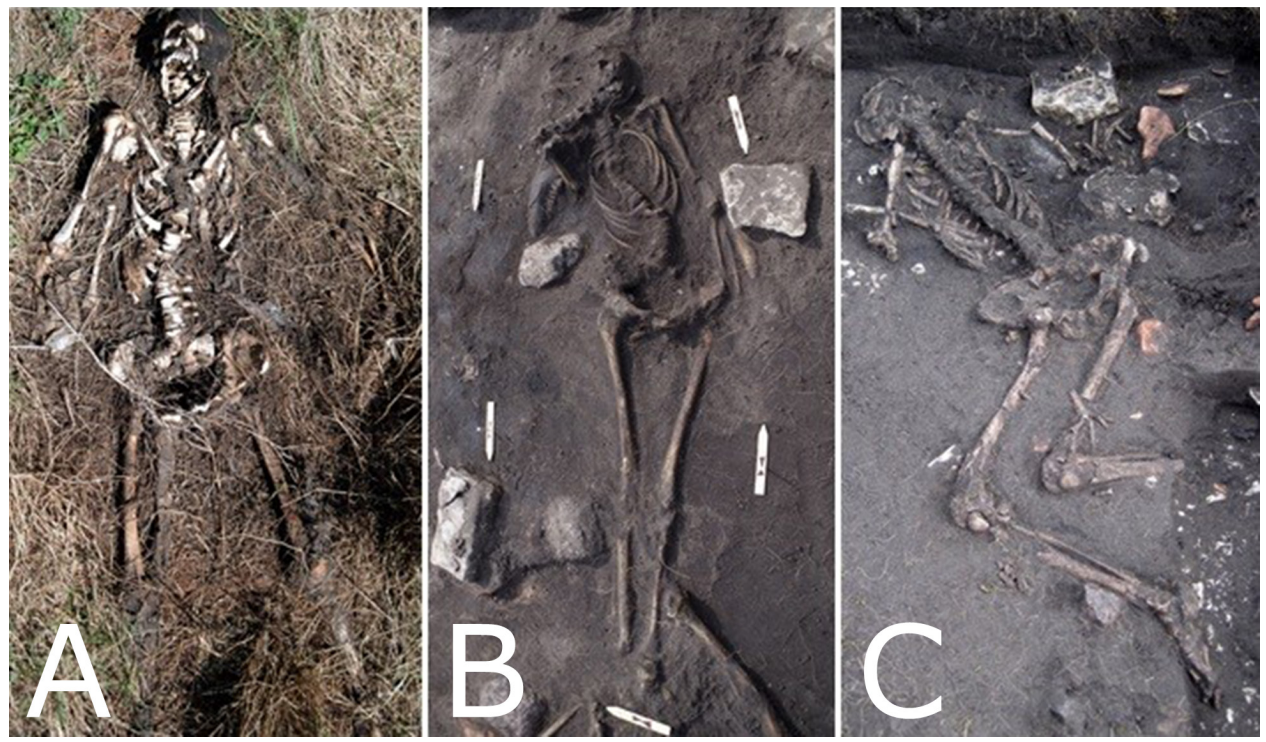

Figure 10. $A$ : The skeleton of a body that decomposed on the ground, showing modest disengagements in the pelvic girdle, femoral heads still in the acetabulum, and ribs in anatomical position (photo by Alfsdotter, published courtesy of the Forensic Anthropology Center at Texas State). B: ID6 from Sandby borg during excavation, showing very modest disengagement in the sacroiliac joint and the pubic symphysis. The femora are still in the acetabulum but the patellae are missing (photo courtesy of the Kalmar County Museum). $C$ : ID1 shows no separation in the pubic symphysis, slight sacroiliac joint disengagement, and femora still in the acetabulum. Note that the patellae are still in anatomical position. Movements outside of the initial volume of the cadaver are seen in the upper limbs. The shaft of the right radius was encountered in front of the left femur (photo courtesy of the Kalmar County Museum).
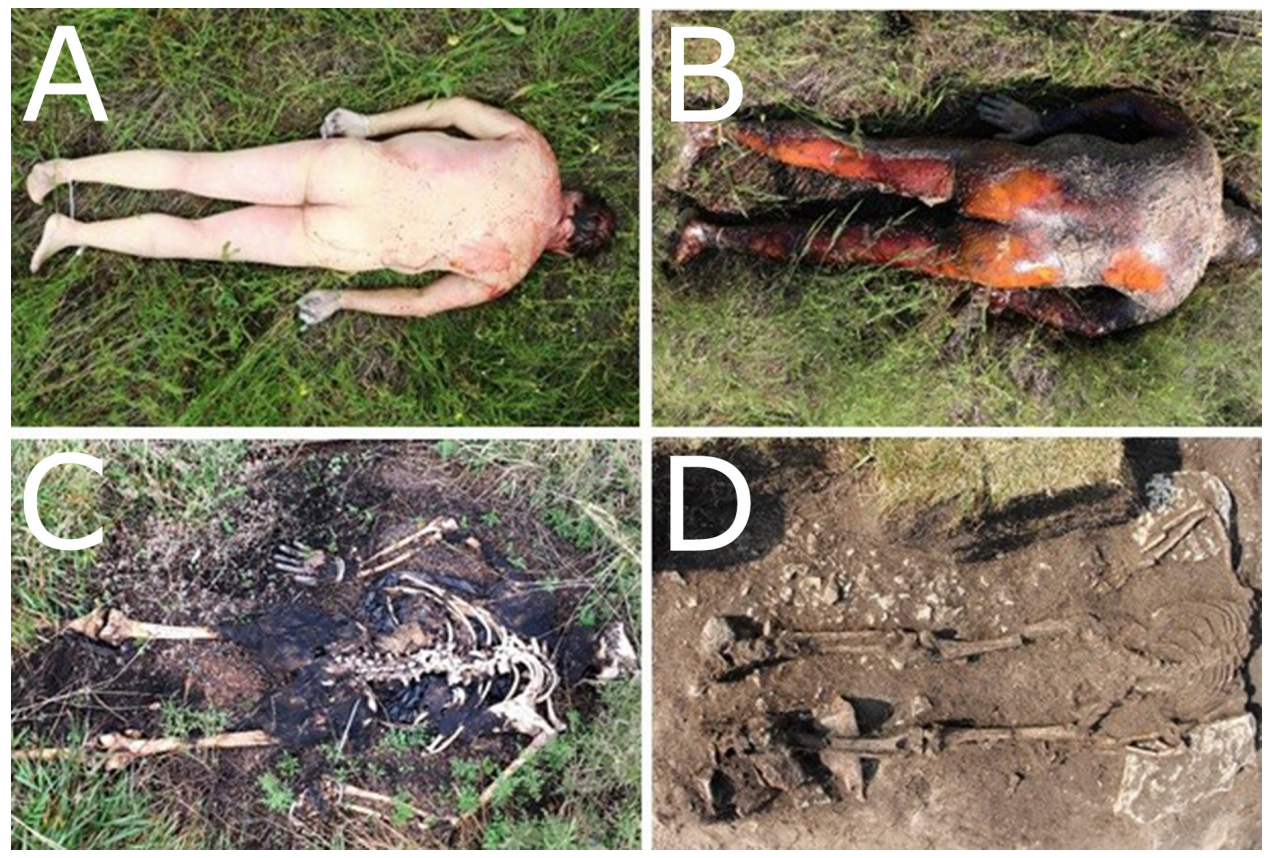

Figure 11. A-C: A willed donated cadaver decomposed in a prone position on the ground. Note the increased abduction of the upper limbs during and after bloat (photos courtesy of the Forensic Anthropology Center at Texas State). $D$ : The position of the upper extremities of ID2 might be the result of the movement of limbs during bloat and can thus be indicative of primary deposition of the body as well as decomposition in an unconfined void. Note the correspondence with the skeleton from FACTS (Photo courtesy of Nicoló Dell'Unto, Institute of Archaeology and Ancient History, Lund University.) 


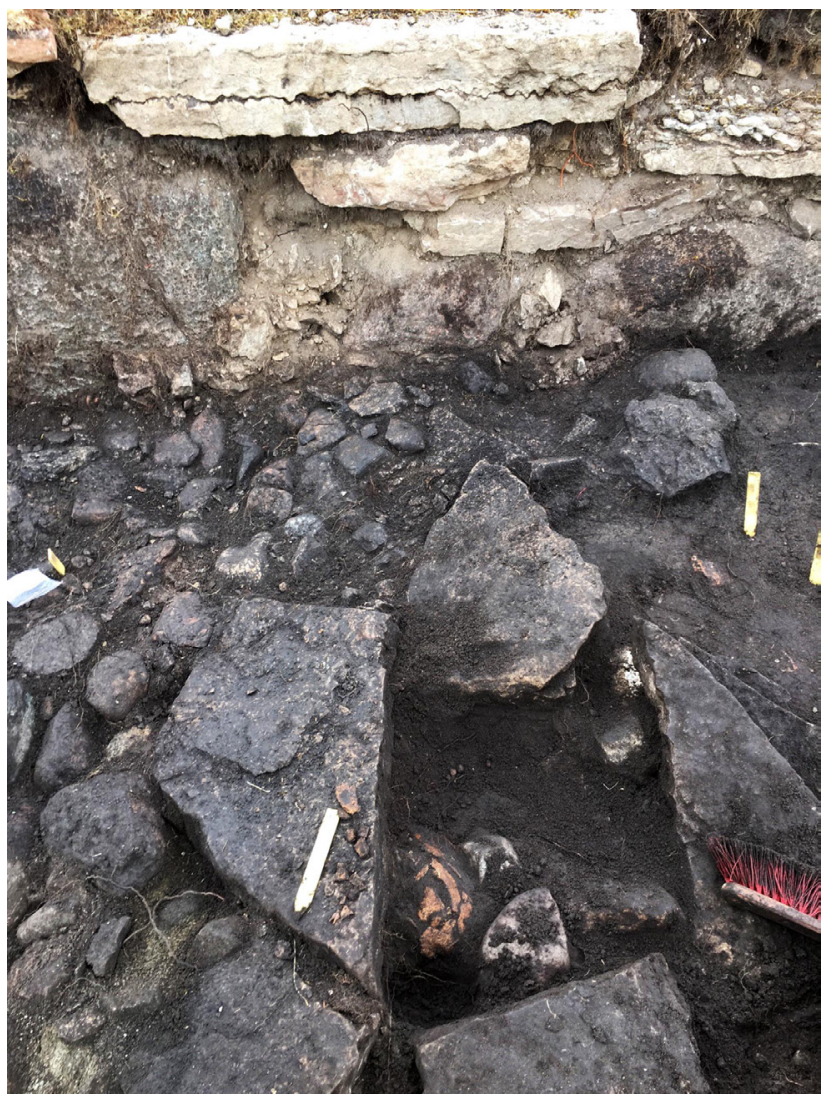

Figure 12. The skull (cranium and mandible) of ID15 was found covered by stone debris from collapse of the far wall of house 4 . Scenarios like this one indicate that the skeletons were not covered by sediment prior to the house collapse. As the fractures are postmortem, the bodies were not fresh when the collapse took place. (Photo courtesy of the Kalmar County Museum.)

house debris and stone substrata in comparison with skeletons that were found adjacent to stones. Another factor is whether the stone walls or the turf roof were first to cave in on the skeletons, since the turf is soft and could act as cushioning of subsequently falling stones. However, roof beams or roof supporting poles would act differently. We cannot know with certainty if these particular houses had lofts or not. Indoors, it appears as though both organic remains (turf/wood?) and stones from walls have affected different skeletons to varying degrees.

\section{Animal activity, thermal alterations, and bone preservation}

In most cases, single bones encountered indoors can be associated with adjacent skeletons. It is challenging, however, to comprehend how odd elements ended up in the houses. Two cases of single bones from children were found indoors where no other associated skeletal remains were discovered. In house 40 the shaft of a femur from an infant was discovered, and in house 52 , the humerus of a young child. The latter case might be explained through animal activity. Apart from the juvenile humerus and the incomplete skeleton ID9, a mandible from an adult was found in what was interpreted as a pit dug by a burrowing animal. These observations could indicate animal access to the house and suggest that commingling between the houses and the street took place. If scavenging was the cause for moving single bones or devouring almost complete bodies, the prevalence of adjacent articulated skeletons is hard to explain in relation to the single infant femur encountered in house 40 . No signs of mutilation (except for the decapitation of a child) are evident in the Sandby borg material excavated so far (Alfsdotter and Kjellström 2018).

Based on the model for canid scavenging by Haglund (1997a:Table 1), and the likely scenario that dogs must have had access to at least some of the exposed bodies, since carcasses were never buried, total disarticulation could be expected. However, only one human element with likely carnivore tooth marks has been identified, despite the finds of articulated dog skeletons inside two houses with human remains. One reason for the lack of carnivore tooth marks could be the poor preservation of the skeletal surfaces where identifiable signs of scavenging have been destroyed. Another possible explanation could be that all larger predators died together with the humans. Alternatively, the carnivores might have devoured complete bones, thus leaving no traces in the skeletal material. Could garments or clothing have protected the bodies from animal access? Details of possible attire related to victims are meager. In house 40 , two small silver fittings were found adjacent to the skeletonized feet from two different individuals.

Presence of rodent gnawing (houses 4, 40, and 52) shows that rodents had access to the bodies. The scavenging may involve all types of human tissue from fresh or mummified cadavers to dry bone (Haglund 1997b). Small bones can be dispersed by animals. The damage pattern on bones varies among rodent species. Rodents preferring mineral content choose parts of bones with thick cortical bone, often leaving "saw marks" along edges of bones. Rodents feasting on fat foremost attack fatter cancellous bone (Klippel and Synstelien 2007). The pattern in Sandby borg is consistent with gnawing on thick cortical regions (for example on the linea aspera of left femur in house 52) not involving the cancellous bone, implying that the mineral content was the target and suggesting that most of the soft tissue was gone at the time of scavenging, in accordance with the observation by Wilhelmson and Dell'Unto (2015). 
Regarding thermal alterations, the middle section of house 40 (containing remains from at least nine individuals) has been affected by fire, likely in connection with the lethal violent event as suggested by the perimortem skeletal modification. The cultural layer surrounding the skeletons in this section is partially burnt, and charred chunks of wood (perhaps remnants of inventory or beams) were found. The layer is interpreted as (at least partially) the remains of the burnt roof (Gunnarsson et al. 2016). Animal activity and weathering in combination with further house demolition or collapse could have led to the partial disarticulation of skeletons in this house section if the roof was partly consumed by the fire. In both the section closest to the house entrance and the section at the far end of the house, human remains and cultural layers display no fire modification, and the skeletons are articulated to a greater extent (Fig. 5). This observation implies a subdivision of the house with different taphonomic situations evident. The human remains of two individuals that were modestly affected by fire outdoors were found adjacent to houses and might be the result of smoldering roofs. Turf roofs usually selfextinguish before they are completely destroyed (Arén, personal communication, cited in Papmehl-Dufay and Alfsdotter 2016), which was probably the scenario in Sandby borg. No house excavated so far was burned to the ground. As for the two other houses (4 and 52) with very limited thermal alteration of bone, the cause seems to be active hearths in contact with parts of bodies. It is unlikely that fire was the manner of death of these individuals. Judging from the archaeological contexts, the fire affected the bodies following death.

The fragmented and commingled human remains found on the street tread level are most simply explained as the result of void decomposition outdoors. It is interesting to note that the FFI and the weathering are similar for the human remains outdoors and indoors. Is this a result of longer exposure indoors? That is, has sand and vegetation covered the skeletons outdoors prior to the collapse of the houses over the skeletons? The archaeological strata show that the indoor skeletons have been exposed to extensive demolition from stone walls, which could explain the high presence of postmortem fractures. It should be noted, however, that rubble from some houses also affected the adjacent outside area when parts of walls collapsed outward. Outdoors, a spatial difference in preservation was noted. In the small alley leading up to a ringfort gate, bones were better preserved than on the larger street (i.e., concentrations of bone elements, some with refitting). One hypothesis regarding the differential preservation is that the bodies in the alley were less exposed to weathering (e.g., sun bleaching and hard winds), due to the partial protection from surrounding house walls. It is also possible that the alley was covered.

\section{Conclusion}

The results of the taphonomic analysis of the skeletons from Sandby borg suggest that the bodies were not manipulated postmortem. The individuals seem to have been left behind where they died and the bodies decomposed in voids. We propose two new observations for unconfined void taphonomy. First, abduction of upper limbs could indicate bloating and may thus be indicative of a primary deposit of the body and decomposition in an unconfined void. Interpretations of limb positions (as part of funerary choices) should thus be made with caution if a body decomposed in an open space. Second, decomposition in unconfined voids might allow quicker drainage than "confined voids," possibly limiting extensive lateral displacements of skeletons. Lateralization of femoral heads, splaying of the pelvic girdle and ribs, often observed in void burials, could possibly be the effect of partial submersion of the cadaver in the putrefaction mass or groundwater rather than the result of gravity alone. Actualistic taphonomic studies are needed in order to validate or challenge the presented hypothesis (Alfsdotter forthcoming), since observation of archaeological skeletons does not account for equifinality.

Indoors, different substrata and falling debris have created diverse taphonomic situations for different skeletal remains in Sandby borg. Animal activity has to some extent affected the human remains. Although the zonation system clearly demonstrated that the elements are larger in size indoors than on the street, no clear differences have been established in the degree of weathering and postmortem fractures. Hence, there is no clear evidence of difference in preservation that could possibly be expected between indoor and outdoor skeletons. However, the identification of long bones in the street is probably reduced, given the vast amount of long bone fragments that can no longer be identified morphologically. Bone units containing several skeletal elements from the same individuals (see Material and Methods) might indicate primary decomposition of the bodies in the area where those bones were recovered outdoors, unless large parts of the same cadavers were moved early in the decomposition phase.

The thermal alterations evident on some of the skeletons seemingly stem from perimortem burning. The modest prevalence and degree of thermal 
modification, together with very localized occurrence of fires, makes it unlikely that fire caused the death of individuals. We interpret the fire alterations as the result of active hearths and smoldering roofs (lit in connection with the assault?) that eventually self-extinguished.

This detailed taphonomic analysis demonstrates that information regarding the postmortem fate of human remains can be derived on a general level and that individual cases can be studied in order to obtain an in-depth understanding of both spatiality and the course of events. We also show that, by combining osteological analysis (here thermal modification) with detailed taphonomic analysis, understanding of the archaeological context is improved.

\section{Acknowledgments}

This work was supported by the Riksbankens Jubileumsfond (grant number P15-0138:1, 2016) and by the Graduate School in Contract Archaeology, Linnaeus University. We thank the staff and students at the Forensic Anthropology Center at Texas State University, Helena Victor, Daniel Lindskog, Sebastian Jakobsson, and Nicolo Dell'Unto for allowing us to use their photos and figures. We also thank Anders Högberg for comments on previous versions of this manuscript. We thank Liv Nilsson Stutz for advising initial archaeothanatological analysis. We thank Aaron Stutz for comments and language review, and Anne Hoffman for help with the German abstract translation. Last but not least, we are grateful for the valuable feedback from editors and the anonymous reviewers.

\section{Supplemental Materials}

Additional supplemental information may be found online with the electronic version of the article.

\section{References Cited}

Alfsdotter, Clara. Forthcoming. The decomposition of human cadavers: An experimental study of joint disarticulation and depositional space.

Alfsdotter, Clara. Humanosteologi i Sandby borg. In press. In Sandby borg IX: Undersökningar 2016, Sandby sn, Mörbylånga kommun, Öland, edited by Ludvig Papmehl-Dufay and Helena Victor. Report prepared for Kalmar läns museum.

Alfsdotter, Clara, and Anna Kjellström. 2018. The Sandby borg massacre: Interpersonal violence and the demography of the dead. European Journal of Archaeology 22(2):210-231. DOI: 10 .1017/eaa.2018.55.
Alfsdotter, Clara, Ludvig Papmehl-Dufay, and Helena Victor. 2018. A moment frozen in time: Evidence of a late fifth-century massacre at Sandby borg. Antiquity 92(362):421-436. DOI: 10 .15184/aqy.2018.21.

Appleby, Jo. 2016. Archaeothanatology in the Englishspeaking world: The belated spread and potential applications of a methodologically rigorous approach to mortuary analysis. In What Bones Tell Us/El Que Ens Expliquen Els Ossos, edited by Lluís Lloveras, Carme Rissech, Jordi Nadal and Josep Maria Fullola. SERP/University of Barcelona, pp. 13-24.

Behrensmeyer, Anna K. 1978. Taphonomic and ecologic information from bone weathering. Paleobiology 4(2):150-162. DOI: 10 .1017/S0094837300005820.

Berryman, Hugh E. 2002. Disarticulation pattern and tooth mark artifacts associated with pig scavenging of human remains: A case study. In Advances in Forensic Taphonomy, edited by William D. Haglund and Marcella H. Sorg. CRC Press, Boca Raton, FL, pp. 487-495.

Bontrager, Amanda, and Stephen P. Nawrocki. 2015. A taphonomic analysis of human creamains from the Fox Hollow Farm serial homicide site. In The Analysis of Burned Human Remains, edited by Christopher W. Schmidt and Steven A. Symes. 2nd ed. Elsevier, Amsterdam, pp. 229-245.

Boquin, Denis, Jean-Pol Beauthier, and Germain Depierre. 2013. The dead do not dress: Contribution of forensic anthropology experiments to burial practices analysis. Proceedings of the 17th International Conference on Cultural Heritage and New Technologies 2012 (CHNT 17, 2012). Museen der Stadt Wien, Vienna, pp. 1-16.

Borg, Kaj, Ulf Näsman, and Erik Wegraneus. 1976. Eketorp: Fortification and Settlement on Öland/Sweden. The Monument. Royal Academy of Letters, History and Antiquities, Stockholm.

Buikstra, Jane E., and Douglas H. Ubelaker. 1994. Standards for Data Collection from Human Skeletal Remains. Arkansas Archeological Survey Series No. 44, Fayetteville.

DeHaan, John D. 2015. Fire and bodies. In The Analysis of Burned Human Remains, edited by Christopher W. Schmidt and Steven A. Symes. 2nd ed. Elsevier, Amsterdam, pp. 1-17.

Duday, Henri. 1978. Archaéologie funéraire et anthropologie. Cahiers d'Anthropologie 1:55-101.

Duday, Henri. 1987a. Contribution des observations ostéologiques à la chronologie interne des sépultures collectives. In Anthropologie Physique et Archéologie: Méthodes d'Etude des Sépultures, edited by Henri Duday and Claude Masset. C.N.R.S, Paris, pp. 51-59.

Duday, Henri. 1987b. Organisation et fonctionnement d'une sépulture collective néolithique: L'Aven de la Boucle à Corconne (Gard). In Anthropologie Physique et Archéologie: Méthodes d'Etude des Sépultures, edited by Henri Duday and Claude Masset. C.N.R.S, Paris, pp. 89-104.

Duday, Henri. 2006. L'archéothanatologie ou l'archéologie de la mort (Archaeothanatology or The Archaeology of Death). In Social Archaeology of Funerary Remains, edited by Rebecca L. Gowland and Christopher J. Knüsel. Oxbow Books, Oxford, pp. 30-56.

Duday, Henri. 2009. The Archaeology of the Dead: Lectures in Archaeothanatology. Translated by Anna Maria Cipriani and John Pearce. Studies in Funerary Archaeology, vol. 3. Oxbow Books, Oxford.

Duday, Henri, Patrice Courtaud, Éric Crubézy, Pascal Seiller, and Anne-Marie Tillier. 1990. L'anthropologie “de terrain”: Reconnaissance et interprétation des gestes funéraires. Cahiers $d u$ 
Centre de Recherches Anthropologiques 2(3):29-49. DOI: 10 .3406/bmsap.1990.1740/.

Duday, Henri, and Claude Masset, eds. 1987. Anthropologie Physique et Archaéologie: Méthodes d'Etude des Sépultures. C.N.R.S., Paris.

Dutra Leivas, Ivonne, and Helena Victor. 2011. Sandby borg I: Undersökningar 2011, Sandby sn, Mörbylånga kommun, Öland. Kalmar läns museum, Kalmar.

Garland, Neil, and Robert Janaway. 1987. The taphonomy of inhumation burials. In Burial Archaeology: Current Research, Methods, and Developments, edited by Charlotte A. Roberts, Frances Lee, and John Bintliff. British Archaeological Reports International Series 211. University of London, London, pp. 14-38.

Gunnarsson, Fredrik, Helena Victor, and Clara Alfsdotter. 2016. Sandby borg VII: Undersökningar 2015, Sandby sn, Mörbylånga kommun, Öland. Kalmar läns museum, Kalmar.

Haglund, William D. 1997a. Dogs and coyotes: Postmortem involvement with human remains. In Forensic Taphonomy: The Postmortem Fate of Human Remains, edited by William D. Haglund and Marcella H. Sorg. CRC Press, Boca Raton, FL, pp. 367-381.

Haglund, William D. 1997b. Rodent and human remains. In Forensic Taphonomy: The Postmortem Fate of Human Remains, edited by William D. Haglund and Marcella H. Sorg. CRC Press, Boca Raton, FL, pp. 405-413.

Haglund, William D., and Marcella H. Sorg. 1997. Forensic Taphonomy: The Postmortem Fate of Human Remains. CRC Press, Boca Raton, FL.

Heimdahl, Jens. 2016. Växtmakrofossilanalyser. In Sandby borg $V$ : Ögonblicket under markytan. Seminarieundersökning $i$ Sandby borg 2014. Sandby sn, Öland, edited by Ludvig PapmehlDufay and Clara Alfsdotter. Kalmar läns museum, Kalmar, pp. 50-51.

Herrmann, Bernhard. 1977. On histological investigations of cremated human remains. Journal of Human Evolution 6(2):101103. DOI: 10.1016/S0047-2484(77)80112-7.

Klippel, Walter E., and Jennifer A. Synstelien. 2007. Rodents as taphonomic agents: Bone gnawing by brown rats and gray squirrels. Journal of Forensic Science 52(4):765-773. DOI: 10.1111 /j.1556-4029.2007.00467.x.

Knüsel, Christopher, and Alan K. Outram. 2004. Fragmentation: The zonation method applied to fragmented human remains from archaeological and forensic contexts. Environmental Archaeology 9(1):85-97. DOI: 10.1179/env.2004.9.1.85.

Lyman, Lee R., and Gregory L. Fox. 1997. A critical evaluation of bone weathering as an indication of bone assemblage formation. In Forensic Taphonomy: The Postmortem Fate of Human Remains, edited by William D. Haglund and Marcella H. Sorg. CRC Press, Boca Raton, FL, pp. 223-247.

Mickleburgh, Hayley. 2018. Actualistic experimental taphonomy on inhumation burial. In Multidisciplinary Approaches to Forensic Archaeology: Topics Discussed during the European Meetings on Forensic Archaeology (EMFA), edited by Matteo Barone and Mike Groen. Springer, Cham, pp. 105-114.

Mickleburgh, Hayley L., and Daniel J. Wescott. 2018. Controlled experimental observations on joint disarticulation and bone displacement of a human body in an open pit: Implications for funerary archaeology. Journal of Archaeological Science: Reports 20:158-167. DOI: 10.1016/j.jasrep.2018.04.022.

Nilsson, Liv. 1998. Dynamic cadavers. A field-anthropological analysis of the Skateholm II burials. Lund Archaeological Review 4:5-17.

Nilsson Stutz, Liv. 2003. Embodied Rituals and Ritualized Burials. Tracing Ritual Practices in Late Mesolithic Burials. Acta
Archaeologica Lundensia Series in $8^{\circ}$, no. 46. Almqvist \& Wiksell International, Stockholm.

Outram, Alan K. 2002. Bone fracture and within-bone nutrients: An experimentally based method for investigating levels of marrow extraction. In Consuming Passions and Patterns of Consumption, edited by Preston T. Miracle and Nicki Milner. Cambridge: McDonald Institute for Archaeological Research, pp. 51-64.

Papmehl-Dufay, Ludvig, and Clara Alfsdotter, eds. 2016. Sandby borg V: Ögonblicket under markytan. Seminarieundersökning i Sandby borg 2014. Sandby sn, Öland. Kalmar läns museum, Kalmar.

Peressinotto, David. 2007. Chronologie de la Dislocation Articulaire du Squelette Axial et des Ceintures au Cours de la Décomposition du Cadavre: Apports à l'Analyse des Sépultures. Ph.D. dissertation, University of Bordeaux.

Roksandic, Mirjana. 2002. Position of skeletal remains as a key to understanding mortuary behavior. In Advances in Forensic Taphonomy: Method, Theory, and Archaeological Perspectives, edited by William D. Haglund and Marcella H. Sorg. CRC Press, Boca Raton, FL, pp. 99-117.

Roksandic, Mirjana, and Stephanie D. Armstrong. 2011. Using the life history model to set the stage(s) of growth and senescence in bioarchaeology and paleodemography. Journal of Physical Anthropology 145(3):337-347. DOI: 10.1002/ajpa.21508.

Schmidt, Cristopher W., Elizabeth Oakley, Ruggero D’Anastasio, Rebecca Brower, Ashley Remy, and Joan Viciano. 2015. Herculaneum. In The Analysis of Burned Human Remains, edited by Christopher W. Schmidt and Steven A. Symes. 2nd ed. Elsevier, Amsterdam, pp. 149-161.

Stiner, Mary C., Steven L. Kuhn, Stephen Weiner, and Ofer BarYosef. 1995. Differential burning, recrystallization, and fragmentation of archaeological bone. Journal of Archaeological Science 22(2):223-237. DOI: 10.1006/jasc.1995.0024.

Symes, Steven A., Christopher Rainwater, Erin N. Chapman, Desina Rachael Gipson, and Andrea L. Piper. 2015. Patterned thermal destruction of human remains in a forensic setting. In The Analysis of Burned Human Remains, edited by Christopher W. Schmidt and Steven A. Symes. 2nd ed. Elsevier, Amsterdam, pp. 17-60.

Ubelaker, Douglas. 2015. The concept of perimortem in forensic science. In Trends in Biological Anthropology 1, edited by Kathleen McSweeney and Karina Gerdau-Radonić. Oxbow Books, Oxford, pp. 93-99.

Viberg, Andreas. 2012. Remnant Echoes of the Past: Archaeological Geophysical Prospection in Sweden. Theses and Papers in Scientific Archaeology 13. Stockholm University, Stockholm.

Viberg, Andreas, Helena Victor, Svante Fischer, Kerstin Lidén, and Anders Andréen. 2014. The ringfort by the sea: Archaeological geophysical prospection and excavations at Sandby borg (Öland). Archäologisches Korrespondenzblatt 44(3):413-428.

Victor, Helena. 2015. Sandby borg: Ett fruset ögonblick under folkvandringstiden. In Grävda minnen: Från Skedemosse till Sandby borg, edited by Kjell-Håkan Arnell and Ludvig PapmehlDufay. Meddelanden från Kalmar läns hembygdsförbund och Stiftelsen Kalmar läns museum, årg. 95. Kalmar läns museum, Kalmar, pp. 96-115.

Victor, Helena, Andreas Emilsson, and Mattias Frisk. 2013. Sandby borg III: Undersökningar 2013. Sandby sn, Mörbylånga kommun, Öland. Kalmar: Kalmar läns museum.

Wilder, Harris Hawthorne. 1923. Notes on the Indians of southern Massachusetts. American Anthropologist 25(2):197-218.

Wilder, Harris Hawthorne, and Ralph Wheaton Whipple. 1917. The position of the body in aboriginal interments in western 
Massachusetts. American Anthropologist 19(3):372-387. DOI: 10 .1525/aa.1917.19.3.02a00030.

Wilhelmson, Helene. 2017. Perspectives from a Human-Centred Archaeology-Iron Age People and Society on Öland. Ph.D. dissertation, Lund University.
Wilhelmson, Helene, and Nicoló Dell'Unto. 2015. Virtual taphonomy: A new method integrating excavation and postprocessing in an archaeological context. American Journal of Physical Anthropology 157(2):305-321. DOI: 10.1002/ajpa .22715 . 